Review

\title{
Persistence of pesticides-based contaminants in the environment and their effective degradation using laccase-assisted biocatalytic systems
}

\author{
Muhammad Bilal ${ }^{a}$, Hafiz M.N. Iqbal ${ }^{\text {b, } * \text {, Damiá Barceló }}{ }^{\mathrm{c}, \mathrm{d}, \mathrm{e}}$ \\ a School of Life Science and Food Engineering, Huaiyin Institute of Technology, Huaian 223003, China \\ b Tecnologico de Monterrey, School of Engineering and Sciences, Campus Monterrey, Ave. Eugenio Garza Sada 2501, Monterrey, N.L. CP 64849, Mexico \\ ${ }^{c}$ Department of Environmental Chemistry, IDAEA-CSIC, Jordi Girona 18-26, Barcelona 08034, Spain \\ d ICRA, Catalan Institute for Water Research, University of Girona, Emili Grahit 101, Girona 17003, Spain \\ e Botany and Microbiology Department, College of Science, King Saud University, PO Box 2455, Riyadh 11451, Saudi Arabia
}

\section{A R T I C L E I N F O}

\section{Article history:}

Received 12 May 2019

Received in revised form 11 August 2019

Accepted 11 August 2019

Available online $\mathrm{xxx}$

Editor: Paola Verlicchi

Keywords:

Pesticides

Environmental impact

Biocatalytic degradation

Laccase

Redox mediators

Enzyme immobilization

\begin{abstract}
A B S T R A C T
Inevitable use of pesticides due to modern agricultural practices and the associated worldwide environmental pollution has called the special attention of the researchers to overcome the persistence, recalcitrance, and multi-faceted toxicity of pesticides-based emerging contaminants. Some restricted use pesticides (RUPs) are highly toxic and carcinogenic chemicals that can be easily accumulated into non-target organisms, including humans, aquatic invertebrates, algae, and microbes. With regard to physicochemical strategies, enzymes-mediated bioremediation is a compelling and meaningful strategy for biodegradation and biotransformation of pesticides into harmless chemical species. Oxidoreductases hydrolases and transferases are among the most representative classes of enzymes pursued and engineered for this purpose. Ligninolytic enzymes, particularly laccases, are of exceptional interest due to high efficiency, specificity, eco-sustainability, and wide-ranging substrates. However, the use of native enzymes is often hindered in industrial processes for the effective removal of refractory compounds by their high cost and susceptibility. Many of these drawbacks can be addressed by enzyme immobilization on some suitable support materials. Increase in stability, reusability, reduction of product inhibition, enhanced activity, specificity, and easier product separation are amid the desirable characteristics of immobilization to construct biocatalysts for continuous systems. This review summarizes recent and up-to-date literature on the use of enzymes, explicitly, free as well as immobilized laccases in the degradation of different pesticides. In the first part, source and occurrence of pesticides in the environment, their types, and associated detrimental effects on the ecosystem/human health are comprehensively described. Afterward, we highlighted the use of different enzymes with a particular emphasis on laccase for the degradation and detoxification of an array of pesticides. Finally, the review is closed with concluding remarks, and possible future direction is proposed in this very important research arena. In conclusion, it is envisioned that effective deployment of laccase-assisted biocatalytic systems for the degradation or removal of diverse pesticides and related contaminants will help to better understand the persistence and removal fate of these hazardous pollutants. Moreover, the current research thrust presented in this review will additionally evoke researcher to engineer robust and sustainable processes to remediate pesticides-contaminated environmental matrices effectively.
\end{abstract}

\section{Introduction}

During the last century, pesticides and other agrochemicals have become an important component of modern global agricultural systems, leading to a substantial improvement in crop yields by controlling insects and disease (Carvalho, 2017; Ali et al., 2019). The exponential increase in the human population further stresses the necessity for augmenting food production. Nevertheless, the extensive applica-

\footnotetext{
* Corresponding author.

Email addresses: hafiz.iqbal@tec.mx (H.M.N. Iqbal); dbcqam@cid.csic.es (D. Barceló)
}

tion of these pesticides possesses several negative influences ranging from ecological pollution to damage of biodiversity (Pico et al., 2018; Barbieri et al., 2019; Köck-Schulmeyer et al., 2019). Dispersion of agrochemical residues in the environment and agriculture land cause disastrous contamination of ecosystems (i.e., dust, soils, air, sediments, and water) and adulterating human foods, around the world (Aamir et al., 2018; Kumar et al., 2018; Li, 2018). Besides, pollution of aquatic systems by pesticide residues also compromised marine food resources, fisheries, and aquaculture. Recently, reports have confirmed the neurotoxic effect of pesticides (Pereira et al., 2015); therefore, widespread exposure to pesticides results in serious health hazards, even directly or indirectly lead to death (Simonelli et al., 2007). 


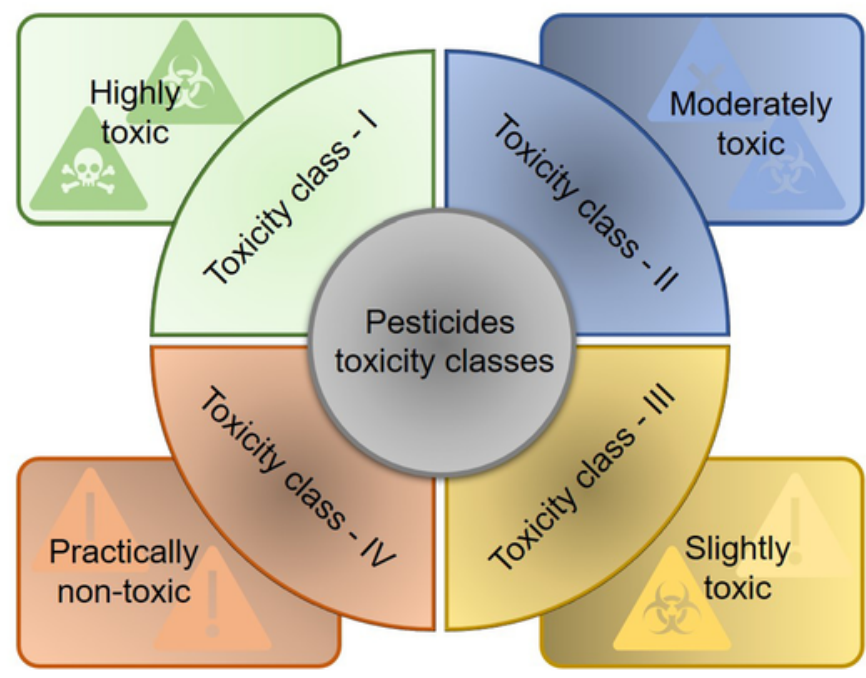

Fig. 1. The EPA categorized toxicity classes of pesticides. The outer boxes represent overall toxicity ratings along with their representative labels.

The US Environmental Protection Agency (EPA) regulates both active ingredients and pesticide formulations under the Federal Insecticide, Fungicide, and Rodenticide Act (FIFRA). The EPA regulations ensure that pesticide usage does not have unreasonable adverse effects on humans and the environment. Based on the legalization and registration process, the EPA has differentiated general use pesticides (GUPs) and restricted use pesticides (RUPs). This differentiation between GUPs and RUPs is primarily based on the toxicity class.
The EPA differentiated toxicity classes of pesticides are shown in Fig. 1. Given the well-documented toxicity and adverse effects of pesticides on different living being systems (Fig. 2), researchers have rekindled their interest in eliminating pesticides from the environment by a range of chemical, physical, and biological approaches (Maqbool et al., 2016; Mir-Tutusaus et al., 2018). However, degradation of pesticides-based pollutants by these methods may not be favorable due to the high cost of treatment, inefficiency, and time-inadequacy (Zeng et al., 2017). The quest for newer, efficient, and environmentally responsive processes has increased importance to tackle the persistence of pesticides and to overcome the issues mentioned above. Many recent studies demonstrated that enzymatic catalysis as "green bioremediation" has drawn substantial attention as attractive alternative and environmentally friendly solution compared to physicochemical methods for the degradation and detoxification of pesticides from diverse environments including soil and aqueous media (Ahmed et al., 2017; Asgher et al., 2014; Bilal et al., 2017). Use of enzyme offers several advantages, including high degradation efficiencies against different pollutants, and stability against varying $\mathrm{pH}$, temperature, and salinity conditions. Moreover, enzyme-mediated treatments are easy to control as no protection and/or de-protection steps involved and essentially have no adverse influence on the environment (Bilal et al., 2018a; Kupski et al., 2019).

Application of the ligninolytic enzymes, particularly laccases are of exceptional interest due to its wide-ranging substrates, and great capability for environmental applications (Jin et al., 2016; Bilal et al., 2017; Chauhan and Jha, 2018; Bilal et al., 2019). Laccases are extracellular glycoproteins with a ubiquitous distribution in nature, ranging from various fungi to higher plants. Laccase enzyme is recog-

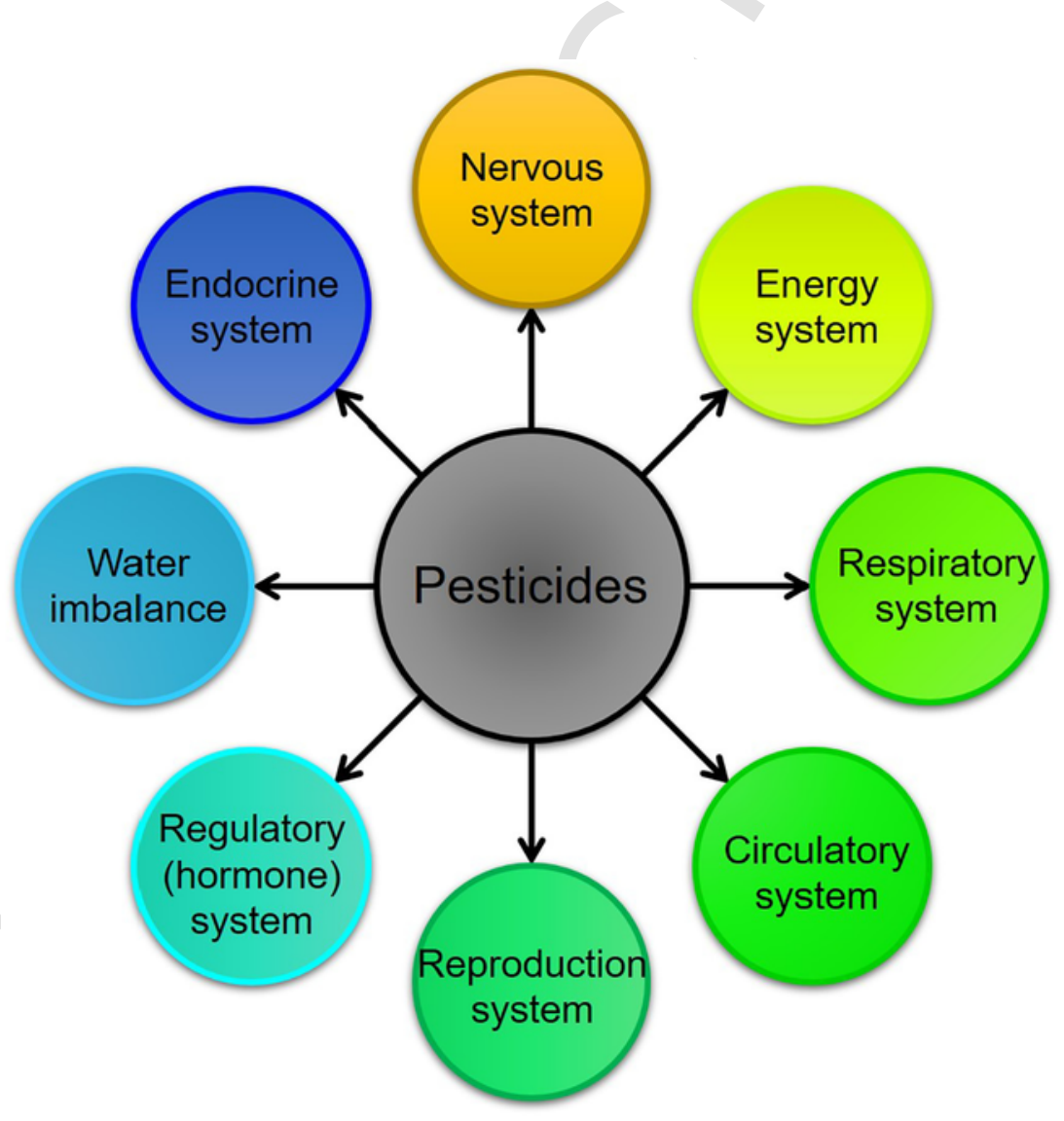

Fig. 2. Human-health related adverse effects of pesticides on different living being systems. 
Table 1

Literature search results obtained from the Scopus database.

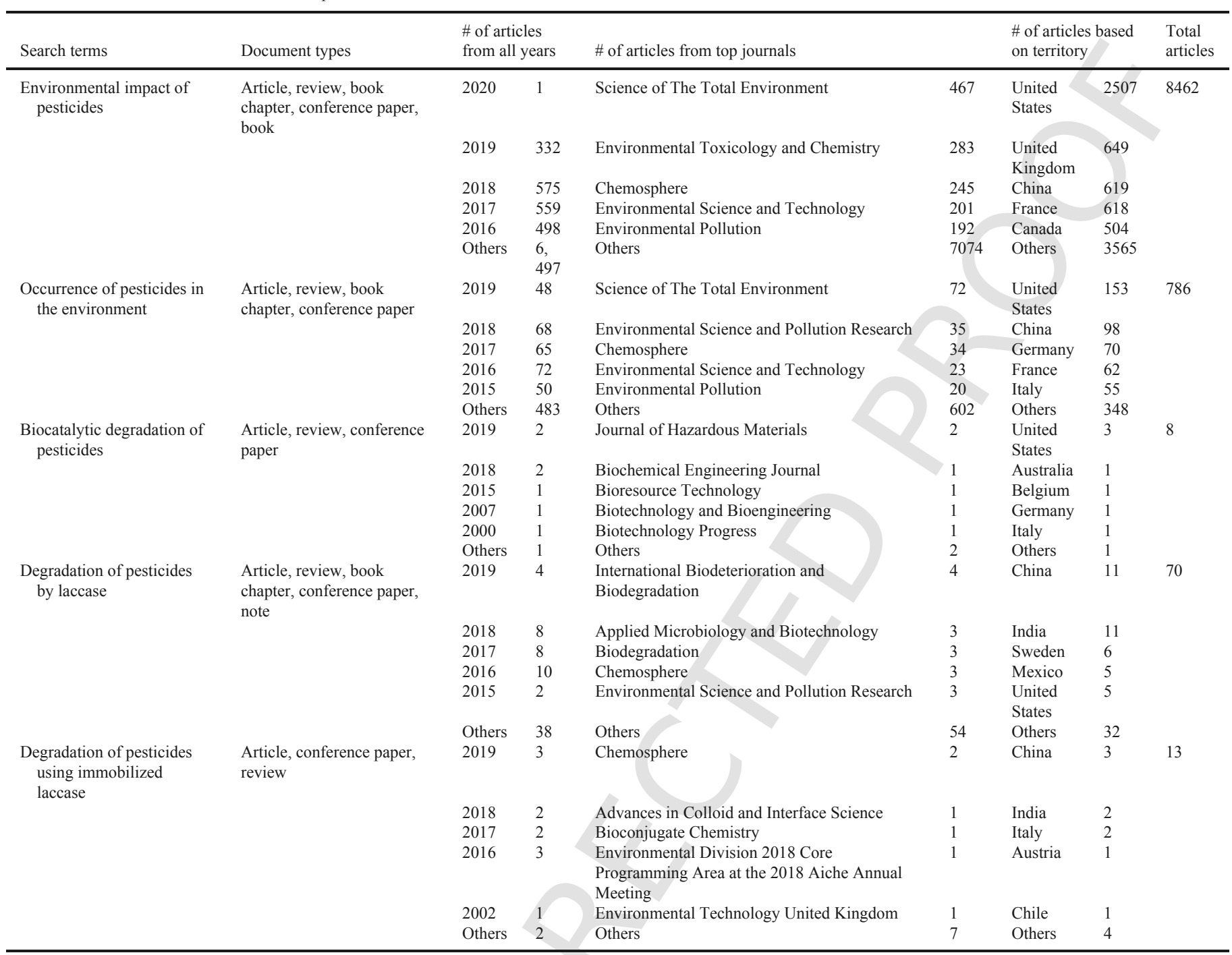

nized to be a proficient, specific, and eco-sustainable biocatalyst, and has been widely applied in various fields, such as dye and wastewater degradation, food-processing industry, paper and pulp industry, and bioremediation of an array of aromatic, xenobiotics, phenolics, and many other recalcitrant pollutants (Zeng et al., 2017; Antecka et al., 2018; Vera et al., 2019; Zdarta et al., 2018a). It can also oxidize non-phenolic compounds in the presence of a suitable natural or synthetic redox mediator. Laccase-mediator systems (LMS), have been observed to bio-transform a variety of toxic pollutants present in dyes, personal care products, and herbicides (Barrios-Estrada et al., 2018; Jankowska et al., 2019).

Despite the numerous advantages as high efficiency, selectivity, low energy necessities, and marginal environmental impact, the employment of native enzyme in industrial processes for the effective removal of refractory compounds is hindered by their high cost and susceptibility (Bilal et al., 2018b, 2018c; Bilal and Iqbal, 2019a). Promisingly, many of the associated drawbacks can be addressed by enzyme immobilization on suitable carrier supports. Increase in stability, reusability, reduction of product inhibition, enhanced activity, specificity, and easier product separation are among the most desirable advantages of immobilization (Zdarta et al., 2018b; Bilal and Iqbal, 2019b; Feng et al., 2019). So far, numerous reports have documented the ameliorated ability of the immobilized form of the laccases in biodegradation and biotransformation of organic pollutants. Nano-porous silica beads-conjugated laccase exhibited about $90 \%$ degradation of 2,4-dinitrophenol within $12 \mathrm{~h}$ and remained stable presenting over $80 \%$ of its original activity even after 30 days of treatment (Dehghanifard et al., 2013). Wang et al. (2012) recorded 2-fold increased phenol removal with magnetic mesoporous silica nanoparticles insolubilized laccase, and the biocatalyst preserved $71.3 \%$ bio-degradation efficiency after ten continuous treatment batches in a fluidized bed. After $8 \mathrm{~h}$ of incubation, $50 \%, 97 \%$, and $71 \%$ degradation of diclofenac, naphthol, and 2,4 dichlorophenol were achieved by the laccase cocktail (Rodríguez-Delgado et al., 2016).

This review summarizes recent and up-to-date literature information on the use of enzymes in the degradation of different pesticides/herbicides/insecticides. After a comprehensive description of the source, occurrence and types of pesticides, and associated detrimental effects on the ecosystem/human health, the use of different enzymes with a special emphasis on free and immobilized laccases for the degradation and detoxification of an array of pesticides is highlighted. 
Table 2

Literature search results obtained from the PubMed database.

\begin{tabular}{clllllll}
\hline Search terms & $\begin{array}{c}\text { Total } \\
\text { articles }\end{array}$ & $\begin{array}{l}\text { \# of articles published in the last five years filtered } \\
\text { with best match term "pesticides." }\end{array}$ \\
\hline $\begin{array}{c}\text { Environmental } \\
\text { impact of } \\
\text { pesticides }\end{array}$ & 10,694 & 963 & 2050 & 1976 & 1963 & 1791 & 1951 \\
$\begin{array}{c}\text { Occurrence of } \\
\text { pesticides in } \\
\text { the } \\
\text { environment }\end{array}$ & 1039 & 92 & 215 & 254 & 213 & 178 & 87 \\
$\begin{array}{c}\text { Biocatalytic } \\
\text { degradation of } \\
\text { pesticides }\end{array}$ & 21 & 4 & 4 & 6 & 1 & 5 & 1 \\
$\begin{array}{c}\text { Degradation of } \\
\text { pesticides by } \\
\text { laccase }\end{array}$ & 60 & 5 & 16 & 11 & 14 & 7 & 7 \\
$\begin{array}{c}\text { Degradation of } \\
\text { pesticides } \\
\text { using } \\
\text { immobilized } \\
\text { laccase }\end{array}$ & 14 & 2 & 5 & 2 & 4 & 1 & - \\
\hline
\end{tabular}

\section{Literature methodology - inclusion/exclusion criteria}

In order to cover the reviewed contents to justify the scientific theme, literature was surveyed from the authentic databases, such as Scopus and PubMed, and discussed following inclusion/exclusion criteria. For initial screening, relevant data was collected based on the existence of all or any of the following terms, i.e., the environmental impact of pesticides; occurrence of pesticides in the environment, biocatalytic degradation of pesticides, degradation of pesticides by laccase, and degradation of pesticides using immobilized laccase, in the article title, abstract and keywords. Table 1 summarizes the search results obtained from the Scopus. The literature search queries were performed on July 9, 2019, at "https://www.scopus.com". In PubMed, the literature was searched for the last five years with the best match term "pesticide". The search results obtained from the PubMed database are summarized in Table 2. Based on inclusion/exclusion criteria, any type of article related to contaminants apart from pesticides and their treatments using strategies other than laccase (free and immobilized) were considered irrelevant to the scope of this review and thus excluded accordingly. The further exclusion was taken into account if none of the searched term was dealt with and discussed in the results section for articles. Following that based on the term "pesticide", a comprehensive literature analysis was performed to overview the detailed classification along with other characteristics features of organophosphorus pesticides, as summarized in Table 3. Based on the literature data obtained, the following sections and subsections were conceptualized and discussed with suitable examples as a core of this review.

\section{Pesticides in the environment - source and occurrence}

The rate of environmental pollution is increasing day-by-day due to anthropogenic activities. The food demand at a rapid pace promotes the use of pesticides (crop protection products) in contemporary agricultural/farming practices at an increasing rate (Morillo and Villaverde, 2017). Ove the past decade, a massive amount of pesticides and other pollutants were released in the atmosphere because of agricultural and industrial development (Morillo and Villaverde, 2017; Varjani et al., 2018). The excessive use of pesticides/chemical fertilizers in modern agriculture practices have led to contamination of different environmental matrices, including air, land, and water. Consequently, the contaminated environmental matrices adversely affect human health and non-targeted animals in several ways (Fig. 3) (Liu et al., 2019). The term 'pesticide' comprehends an array of organic compounds intended to prevent, destroy, or control weeds (herbicide), insects (insecticide), pests (pesticide), and fungi and molds (fungicide) ( Andleeb et al., 2016). Traces of these toxic compounds may enter rivers, surface water, and groundwater through soil leaching, surface run-off, underground run-off, and accidental leakage (Liao et al., 2017; Liu et al., 2019). Reports have revealed the occurrence of OCPs in environmental samples at an elevated level than OPPs in areas, where OCPs are continuously applied for pest management. Higher concentrations of OCPs have also been detected in various body fluids such as breast milk, serum, and urine (Idowu, 2013).

\section{Pesticides and their types}

Pesticides have been classified into different categories based on usage, formulation type, source of origin, mode of action/entry, toxicity, function, and pest organism they kill (Fig. 4). Broadly speaking, pesticides are categorized as either organic or inorganic based on their structure. Along with carbon in the structure, organic pesticides also contain oxygen, fluorine, phosphorus, and chloride sulfur. On the other hand, inorganic pesticides are composed of compounds like copper, sulfur, and other elements. Depending on the functional groups and presence in the same chemical class or family, pesticides have been categorized into four classes/families, i.e., (1) organophosphates, e.g., malathion, (2) carbamates, e.g., carbofuran, (3) triazines, e.g., atrazine, and (4) phenoxys, e.g., 2,4-Dichlorophenoxyacetic acid (2,4-D). Almost all pesticides in the same class/family have similar chemical structure along with a similar mode of action, poisoning symptoms, persistence, first aid, clean-up, and safety guidelines. However, each pesticide has an explicit target site based on the mode of action (Wang et al., 2017).

Organochlorine pesticides (OCPs), composed of carbon, hydrogen, and chlorine, are a large group of chemicals used to repel and destroy weeds, insects, bacterial and fungal impacts (Jayaraj et al., 2016). Fig. 5 illustrates the molecular structures of some selected OCPs. Most of the organochlorines are insecticides such as benzene hexachloride (BHC), dichlorodiphenyltrichloroethane (DDT) and its analogs including aldrin, chlordane dieldrin, endrin, endosulfan, and heptachlor (Katayama and Matsumura, 1993; Jayaraj et al., 2016). These groups of pesticides are white, crystalline, semi-volatile and soluble in organic solvents and fats, and tend to aggregate in the environment and food crops (Barragan-Huerta et al., 2007; Rani et al., 2017). Among the OCPs, DDTs and hexachlorocyclohexanes (HCHs) are the most widely applied OCPs in public health, agriculture, and eradicating tsetse fly, termite, and mosquitoes (Kafilzadeh, 2015; Yahaya et al., 2017). In the past, the large-scale production and use of these pesticides was prohibited and swapped gradually with other pesticides because of their high ecological toxicity, high persistence, health impacts and robust affinity to bioaccumulation cause environmental pollution (Ahmed et al., 2015; Rani et al., 2017; Gopalan and Chenicherry, 2018). For instance, use of Aldrin and dieldrin were banned in Kenya in 1992, and DDT was banned in 1985 (Wandiga, 2001). Similarly, the manufacturing, use, and import of aldrin and dieldrin have been banned in India since 2013, whereas DDT was banned since 1989 (Gopalan and Chenicherry, 2018). OCPs origi- 
Table 3

Classification overview of organophosphorus pesticides ${ }^{\mathrm{a}, \mathrm{b}, \mathrm{c}}$.

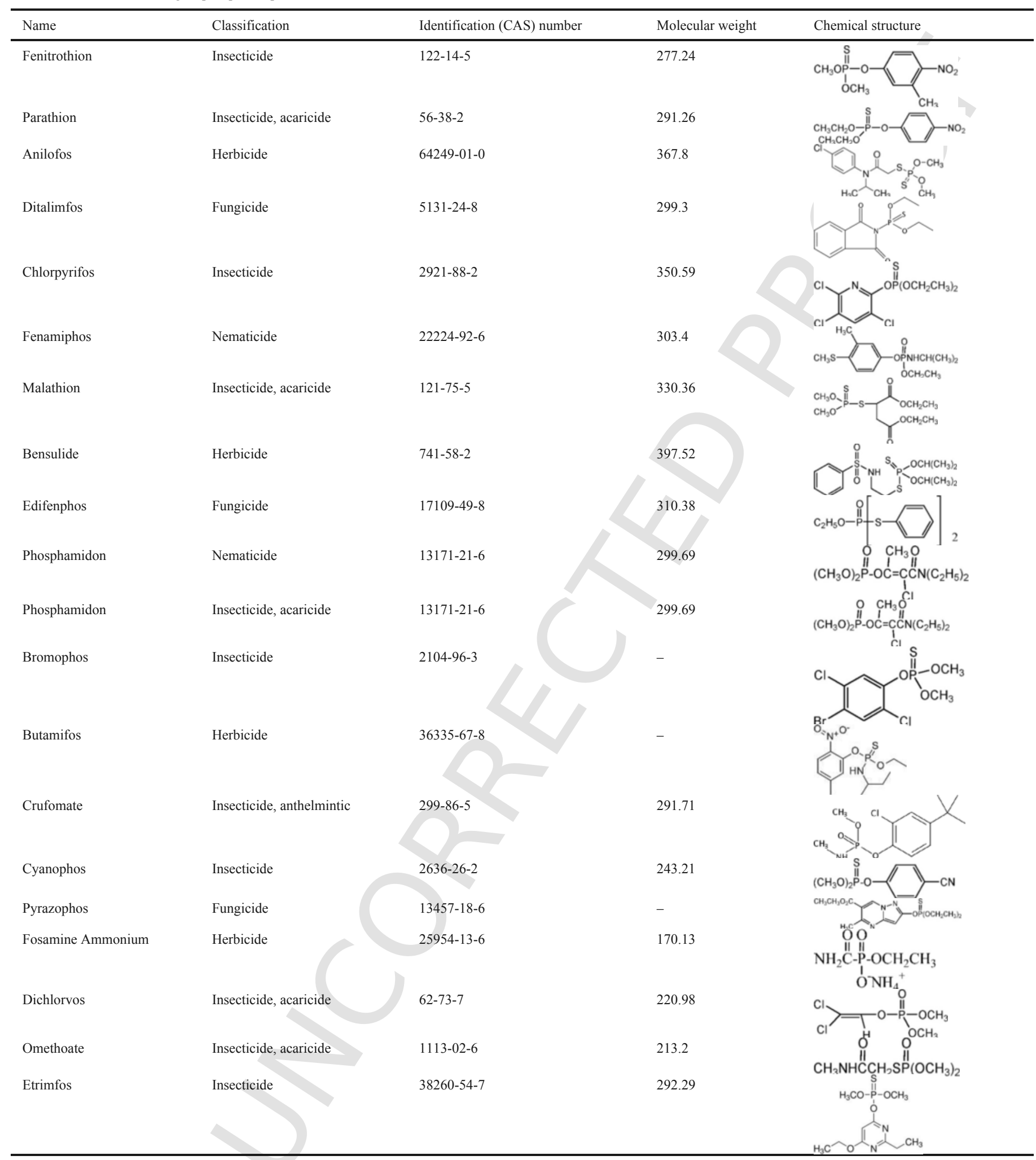


Table 3 (Continued)

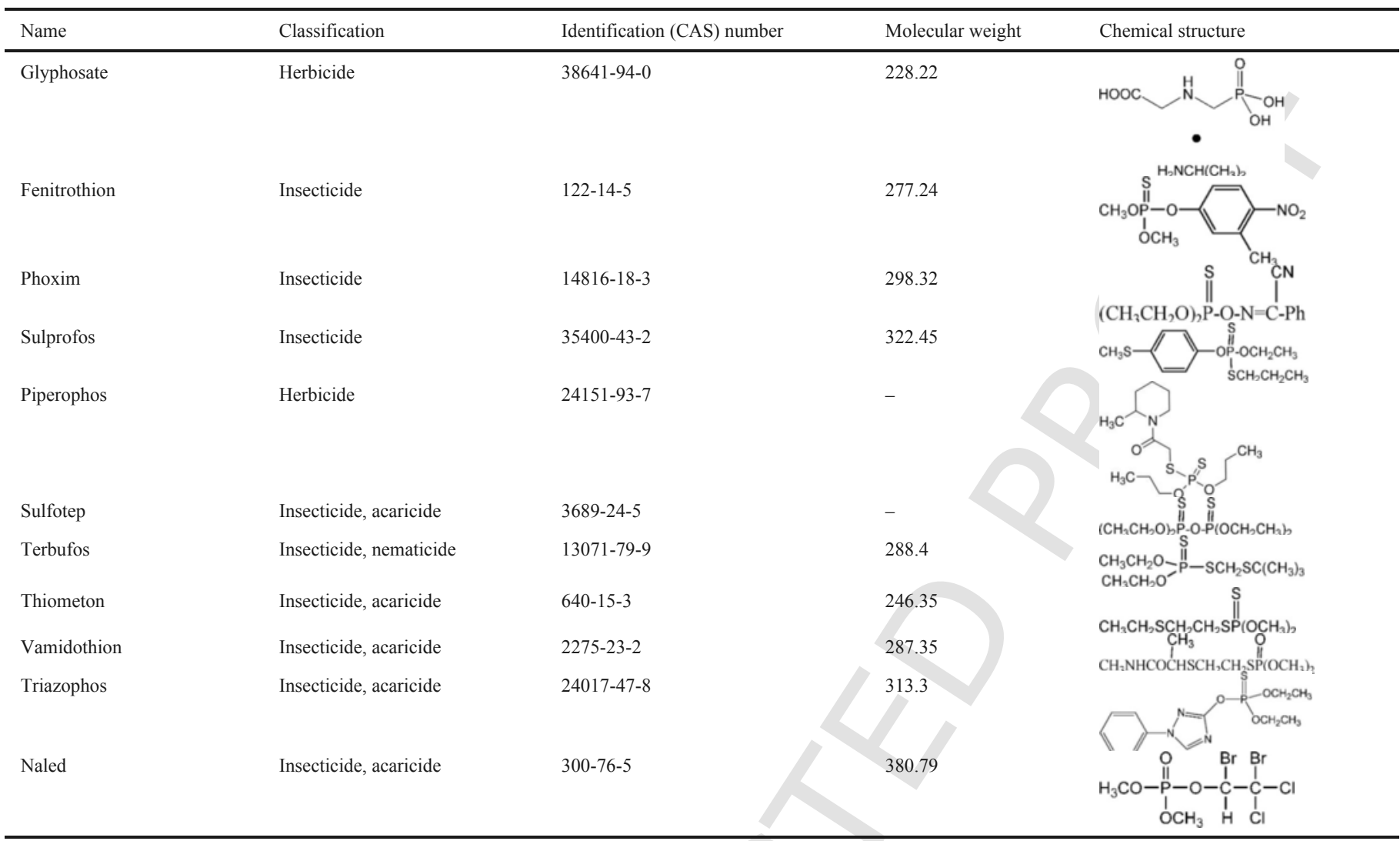

${ }^{a}$ Living beings are prone to organophosphorus pesticides via three major exposure routes, i.e., (1) inhalation, (2) ingestion, and (3) dermal absorption.

b Potential adverse health effects of organophosphorus pesticides includes the inhibition of acetylcholinesterase in the nervous system, respiratory, myocardial and neuromuscular transmission impairment, Intermediate Syndrome, delayed neuropathy, cholinergic syndrome, carcinogenic, mutagenic, teratogenic, nicotinic effects, etc.

${ }^{\mathbf{c}}$ Environment is prone to the organophosphorus pesticides via three major routes of entry, i.e., (1) industrial waste or effluent discharged directly into the environment (water), (2) seepage from buried toxic wastes into the surrounding environment (soil or water), and (3) contamination of running water directly or from run-off during spraying operations can occur.

nated from domestic wastes, industrial effluents, agricultural activities, and other point/nonpoint sources incorporate into environmental components through the air, runoff, and other agents (Ahmed et al., 2015). DDTs and HCHs are often regarded as characteristic compounds to evaluate the ecological status of OCPs, due to their numerous applications, human health, and environmental impact (Gereslassie et al., 2019). Owing to the increasing persistence and adverse effects of DDT on the environment and living beings, the use of DDT as a pesticide was banned worldwide under the Stockholm Convention in 2001.

Organophosphorus pesticides (OPPs) are phosphoric acid esters that can improve both the quality and quantity of crop yields in agricultural practices (Cederlund et al., 2016; Schenk et al., 2016), and used as warfare nerve agents such as sarin, soman, tabun, and others. Their use has been substantially increased in the past decade due to potential efficacy for improving crop productivity. Nevertheless, the widespread use of these pesticides can lead to environmental pollution and posturing a menace to human health and aquatic life. Fenitrothion, parathion, chlorpyrifos, Malathion, and phosphamidon are some examples of OPPs applied in the agricultural fields (Ghanem et al., 2007; Schenk et al., 2016). A detailed classification overview along with other characteristics features of organophosphorus pesticides are summarized in Table 3 . These pesticides can cause acute toxicity to humans when exposed to their elevated levels through irreversible inactivation/inhibition of the acetylcholinesterase en- zyme. This enzyme is indispensable for nerve function in humans, insects, and numerous other animals (Jayaraj et al., 2016; Schenk et al., 2016). It is of profound significance to transform toxic OPPs into harmless compounds to mitigate environmental contamination. Reports have shown that OPPs can be readily hydrolyzed by exposure to air, light, and soil, but traces of these pesticides have been identified in food and drinking water (Jokanović, 2018). Carbamates are pre-emergent herbicides obtained from carbamic acid (Tatarková et al., 2013), such as aldicarb, carbofuran, ethienocarb, oxamyl, and methomyl. Generally, they are employed in the form of baits or sprays in the field to alleviate pests (Zhang et al., 2013). Carbaryl was the first insecticide to be used in the field. It exhibits great potential to control a broad range of insects and is associated with less toxicity to humans. The carbamates possess a similar mode of action to that of OPPs (Hayatsu et al., 2001; Schenk et al., 2016). Plant roots and leaves easily absorb carbamates due to their high-water solubility (Zhang et al., 2013).

\section{Pesticide and human health}

Pesticides are deliberated as an efficient and cost-effective tool for pest management. However, owing to their mechanism of action, they not only destroy the target creature but also damage non-target organism, including humans. The World Health Organization reports approximately 3 million annual cases of pesticide poisoning and up 


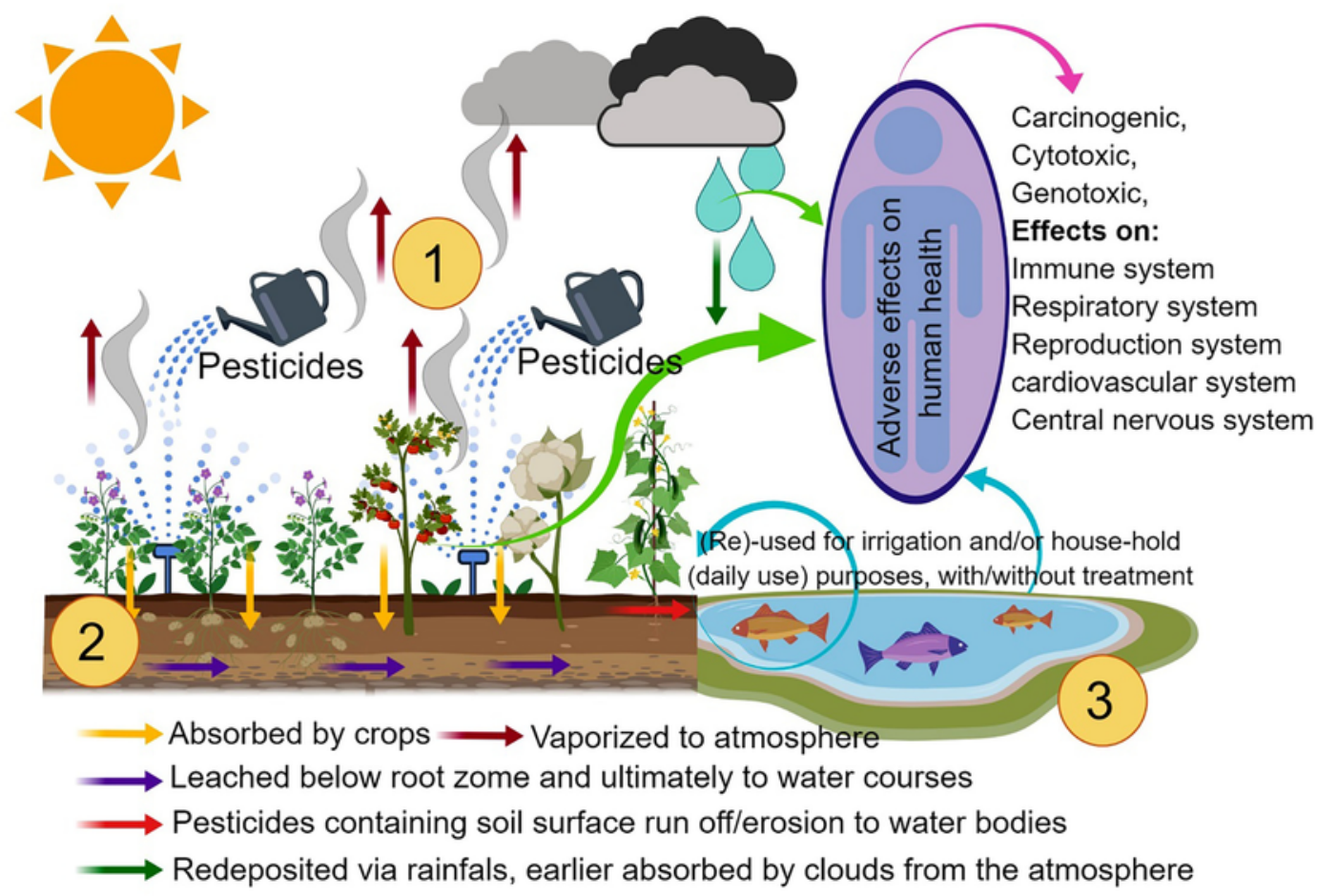

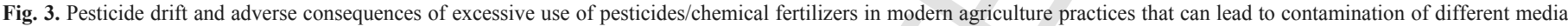
including (1) air, (2) land, and (3) water. Reprinted from Liu et al. (2019), with permission from Elsevier. Copyright (2019) Elsevier B.V.

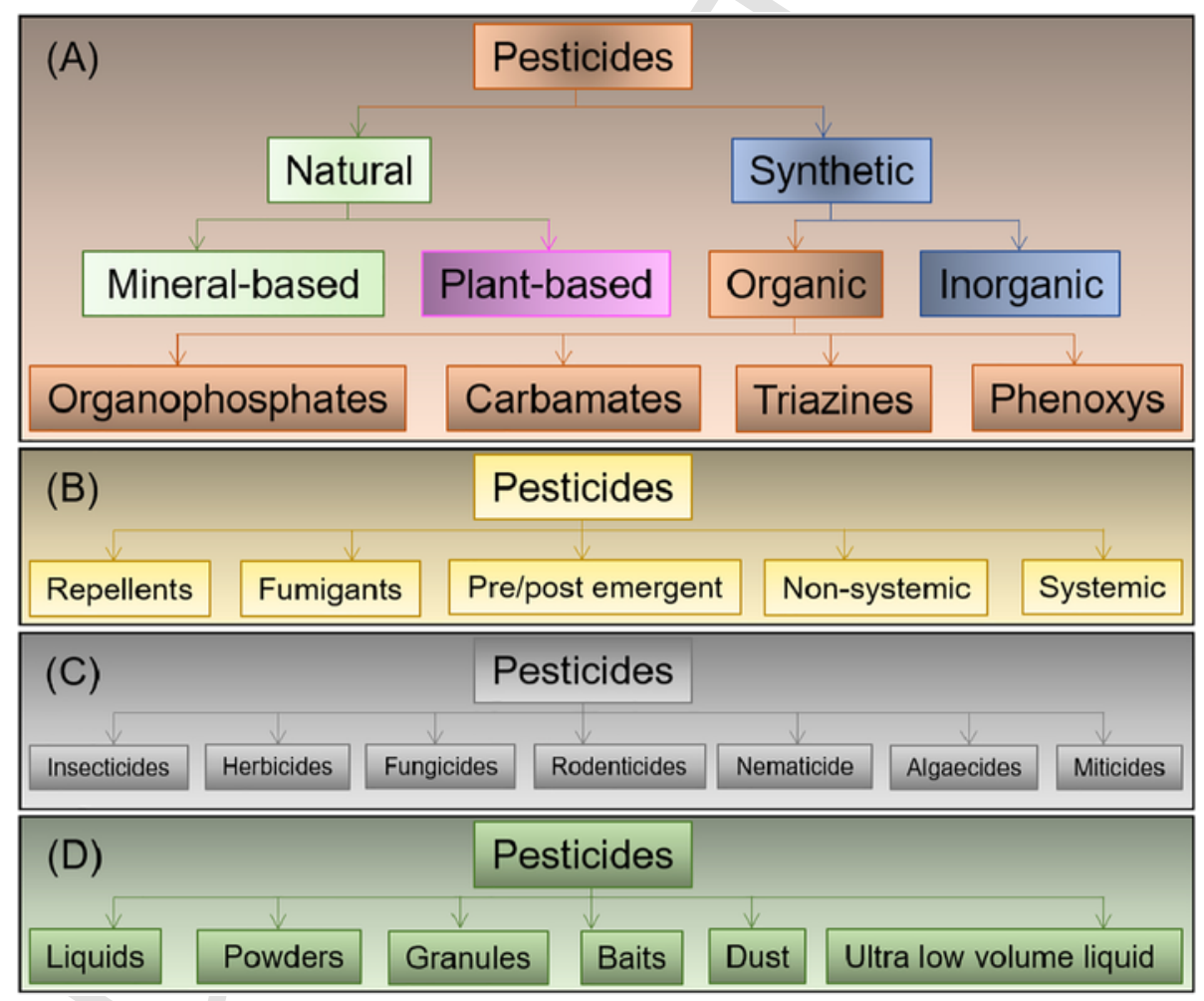

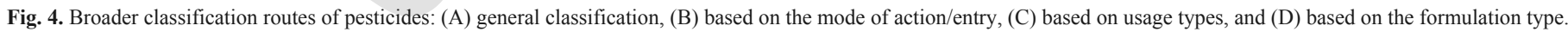

to 220,000 deaths, predominantly in emerging countries. Non-specific use of pesticides and unintentional acquaintances occur to other organisms, particularly, young and developing organisms are highly vulnerable to their detrimental effects. The amount of pesticide as well as the persistence time mainly determined the toxic effect of pesticide exposure. Some pesticides are extremely toxic to hu- 
<smiles>CC1(C)C2(Cl)C(Cl)=C(Cl)C1(Cl)C1(Cl)CC(Cl)C(Cl)C12</smiles>

(A)<smiles>C[13CH3]</smiles>

(B)<smiles>CC(C)(C)C1C(Cl)C2C(Cl)C(Cl)C(Cl)C1C2(Cl)Cl</smiles>

(D)

MW: 295.34<smiles>O=[N+]([O-])c1c(Cl)c(Cl)c(Cl)c(Cl)c1Cl</smiles>

(H)

MW: 284.78<smiles>Clc1c(Cl)c(Cl)c(Cl)c(Cl)c1Cl</smiles>

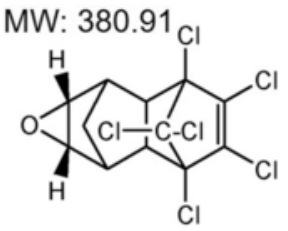

(E)

MW: 303.16<smiles>Clc1ccccc1-c1nnc(-c2ccccc2Cl)nn1</smiles>

(I)

MW: 422.95

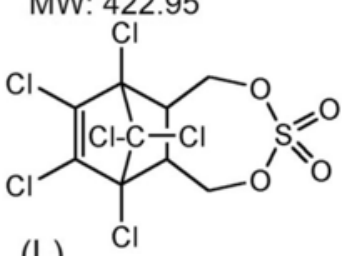

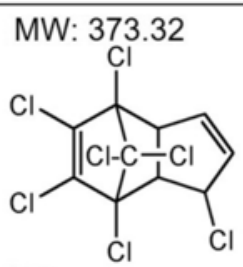

(C)<smiles></smiles>

(F)

(G)

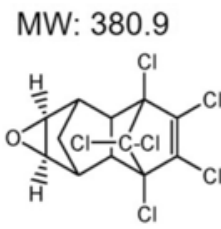

MW: 406.91<smiles>Oc1c(Cl)cc(Cl)c(Cl)c1Cc1c(O)c(Cl)cc(Cl)c1Cl</smiles>

(J)

$$
\text { MW: } 406.93
$$<smiles>CC(C)(C)C1(Cl)C(Cl)=C(Cl)C2(Cl)[C@H]3COS(=O)OC[C@H]1C32Cl</smiles>

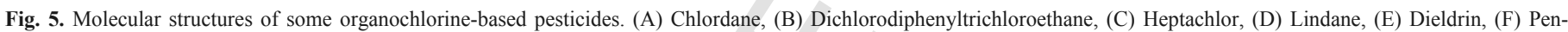
tachlorophenol, (G) Endrin, (H) Pentachloronitrobenzene, (I) Clofentezine, (J) Hexachlorophene, (K) Hexachlorobenzene, (L) Endosulfan sulfate, (M) $\beta$-Endosulfan.

mans resulting in undesirable effects with only a few drops in the mouth or on the skin. Other less toxic pesticides can also cause harmful effects by their continuous and long-term exposure (Singh et al., 2018). Close association of pesticides is associated with diverse health disorders and malignancies such as leukemia, Parkinson's disease, Hodgkin's disease, non-Hodgkin lymphoma, Burkitt lymphoma, respiratory, reproductive, and endocrine disorders (Wang et al., 2014; Luo et al., 2016; Brouwer et al., 2017; Sabarwal et al., 2018). According to the WHO, (2002) many pesticides have been documented as endocrine disruptor compounds (EDCs), which interfere with endocrine systems, leading to devastating consequences on physiological processes, i.e. growth, development, and reproduction in organisms or their offspring.

Some pesticides including maneb, paraquat, and rotenone result in Reactive Oxygen Species (ROS)-mediated oxidative stress and thus several cause neurodegenerative disorders in the body (Fig. 6) (Sabarwal et al., 2018). Parkinson's disease, at the cellular level, is meticulously related to excessive ROS generation from mitochondrial electron transport complexes, which consequently, causes serious damages to mitochondrial DNA and other bio-macromolecules (Nandipati and Litvan, 2016). Likewise, Alzheimer's disease is clinically characterized by the accumulation of an abnormal amyloid protein and is tightly related to oxidative stress. Continuous exposure to dieldrin, paraquat, organophosphates, and organochlorine has observed to produce ROS-driven neurotoxicity, which in turn is cou- pled with Alzheimer's disease (Yan et al., 2016). Various epidemiological and clinical reports have demonstrated a close relationship between pesticide contact and asthma and bronchial hyper-reactivity symptoms. Exposure of agrochemicals or pesticide/herbicides may cause a severe asthma exacerbation by inflammation, irritation, endocrine disruption, or immunosuppression (Kim et al., 2017). In another study, Sylvie Azandjeme et al. (2013) revealed that exposure to OCPs and metabolites is thought to cause a high risk of type 2 diabetes and associated comorbidities. Similarly, OPPs-based pollutants exposure are a potential risk affecting the reproductive system of the male by mechanisms such as a decrease in sperm counts, density, viability, and motility, inhibiting sperm formation, abnormal sperm morphology, and reduction of testis weights (Mehrpour et al., 2014).

\section{Degradation of pesticide-conventional vs. enzyme-mediated bioremediation techniques}

Different physical and chemical strategies have been attempted to confront the persistence of organochlorine pesticides and to reduce their detrimental effects in the ecosystems. For example, He et al. (2011) utilized UV irradiation and ozonation $\left(\mathrm{UV} / \mathrm{O}_{3}\right)$ amalgamated approach to degrade chlorophane (CP) and dichlorophen $\left(2,2^{\prime}\right.$-methylene bis(4-chlorophenol) (DCP) pesticides in the aqueous environment and recorded an increase in the oxidation rate of both pesticides by 1 order of magnitude. Nevertheless, the existence of high or- 


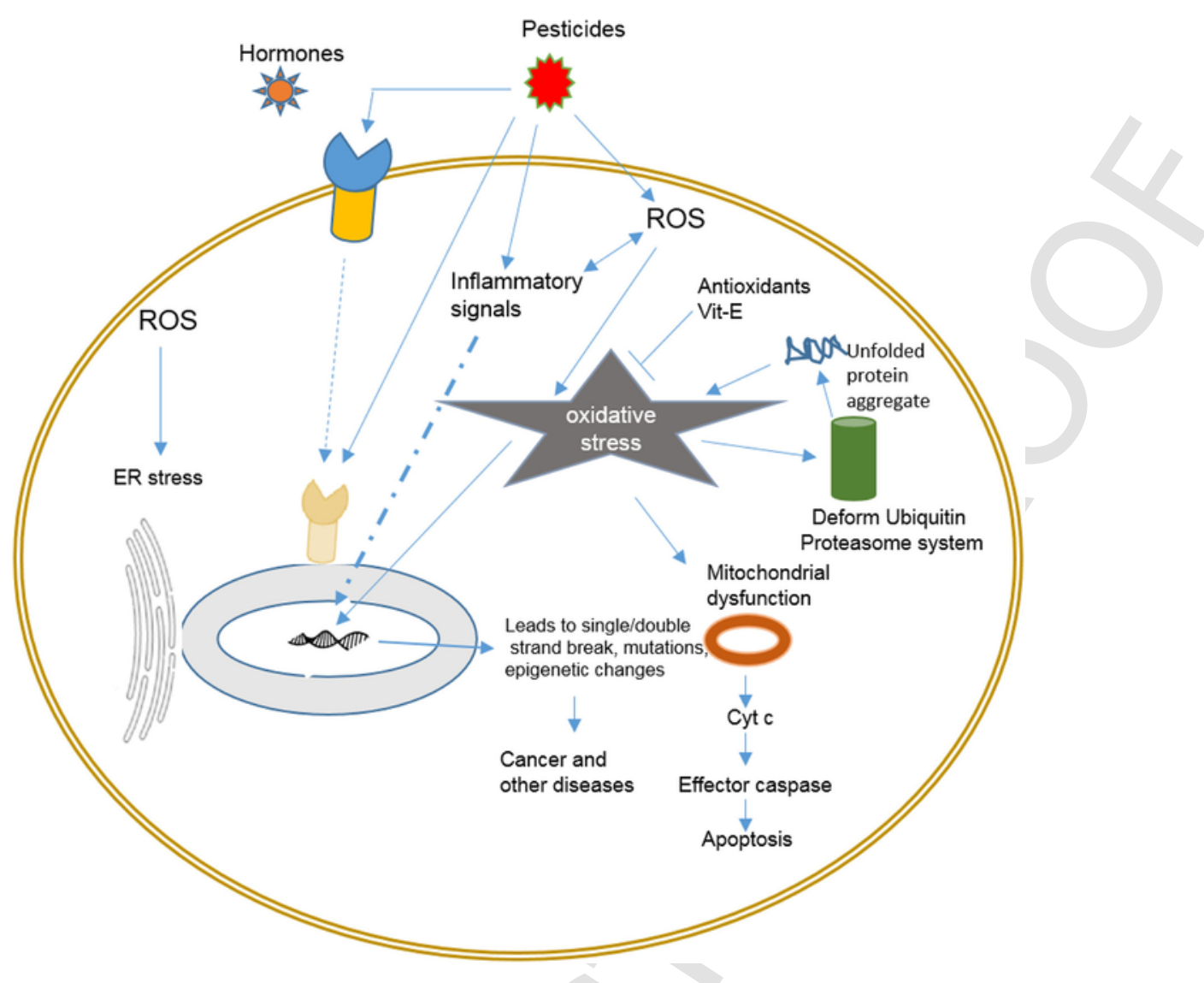

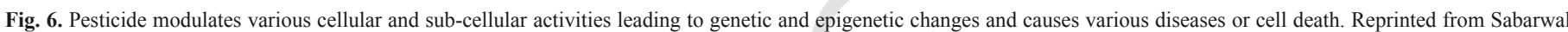
et al. (2018), with permission from Elsevier. Copyright (2018) Elsevier B.V.

Table 4

Degradation studies of various pesticides by free laccases in the presence of different redox mediators.

\begin{tabular}{|c|c|c|c|c|c|c|}
\hline Source of enzyme & Amount of enzyme & Redox mediator & Pesticide & Degradation (\%) & Time & Reference \\
\hline Pseudomonas sp. & $210 \mathrm{nkat} / \mathrm{mL}$ & No/sinapic acid & Chlorpyrifos & $80.56 / 83.25 \%$ & $6 \mathrm{~h}$ & Chauhan and Jha (2018) \\
\hline Pseudomonas sp. & $210 \mathrm{nkat} / \mathrm{mL}$ & $\mathrm{No} /$ sinapic acid & Dichlorophos & $45.99 / 45.82 \%$ & $6 \mathrm{~h}$ & Chauhan and Jha (2018) \\
\hline Pseudomonas sp. & $210 \mathrm{nkat} / \mathrm{mL}$ & No/sinapic acid & Monocrotophos & $75.45 / 78.82 \%$ & $6 \mathrm{~h}$ & Chauhan and Jha (2018) \\
\hline Pseudomonas sp. & $210 \mathrm{nkat} / \mathrm{mL}$ & $\mathrm{No} /$ sinapic acid & Profenovos & $81.84 / 82.15 \%$ & $6 \mathrm{~h}$ & Chauhan and Jha (2018) \\
\hline Trametes versicolor & $0.30 \mathrm{U} / \mathrm{mL}$ & HBT & Isoproturon & $100 \%$ & $24 \mathrm{~h}$ & Zeng et al. (2017) \\
\hline Trametes versicolor & $0.30 \mathrm{U} / \mathrm{mL}$ & HBT & Isoproturon & $68.2 \%$ & $24 \mathrm{~h}$ & Zeng et al. (2017) \\
\hline Trametes versicolor & $0.05 \mathrm{U} / \mathrm{mL}$ & Violuric acid & Pyrimethanil & $100 \%$ & $24 \mathrm{~h}$ & Jin et al. (2016) \\
\hline Trametes versicolor & $0.05 \mathrm{U} / \mathrm{mL}$ & Violuric acid & Isoproturon & $100 \%$ & $24 \mathrm{~h}$ & Jin et al. (2016) \\
\hline Trametes versicolor & $0.05 \mathrm{U} / \mathrm{mL}$ & 1-Hydroxybenzotriazole & Atrazine & $90 \%$ & $8 \mathrm{~d}$ & Jin et al. (2016) \\
\hline Trametes versicolor & $0.05 \mathrm{U} / \mathrm{mL}$ & Acetosyringone & Chlorothalonil & $90 \%$ & $8 \mathrm{~d}$ & Jin et al. (2016) \\
\hline Trametes versicolor & $0.05 \mathrm{U} / \mathrm{mL}$ & Vanillin & Chlorpyrifos & $90 \%$ & $8 \mathrm{~d}$ & Jin et al. (2016) \\
\hline Trametes versicolor & $0.15 \mathrm{U} / \mathrm{mL}$ & ABTS & Glyphosate & $40.9 \%$ & $24 \mathrm{~h}$ & Pizzul et al. (2009) \\
\hline Trametes versicolor & $0.15 \mathrm{U} / \mathrm{mL}$ & $\mathrm{Mn}^{2+}+$ Tween 80 & Glyphosate & $62.8 \%$ & $24 \mathrm{~h}$ & Pizzul et al. (2009) \\
\hline Trametes versicolor & $0.15 \mathrm{U} / \mathrm{mL}$ & $\mathrm{ABTS}+\mathrm{Mn}^{2+}+$ Tween 80 & Glyphosate & $90.1 \%$ & $24 \mathrm{~h}$ & Pizzul et al. (2009) \\
\hline
\end{tabular}

ganic matter in sewage act as a quencher of oxidizing species produced by $\mathrm{UV} / \mathrm{O}_{3}$, and thus decreasing treatment efficacy by $38 \%$. Biotechnological approaches, on the other hand, have also been developed to take advantage of whole organisms, a metabolic trait, or biocatalysts in transforming pesticides into innocuous compounds. In the case of whole microorganisms and metabolic pathways, pesticides are commonly utilized as co-substrates in reactions, where natural substrates are co-transformed along with the pesticide, thus eliminating them from the environment. A range of microbial communities including bacteria (Pseudomonas spp., Rhodococcus sp., Bacillus spp., etc.), as well as, fungi (Aspergillus spp., Botrytis cinera, Tricho- derma harzianum) have the ability to interact with different kinds of pesticides both physically and chemically, leading to structural alterations or complete degradation and transformation of the target molecule (Katayama and Matsumura, 1993; Ortiz-Hernández et al., 2013). Similarly, soluble or isolated enzymes have shown great potential as green catalysts to transform a diversity of natural or artificial substrates, thus circumventing the intricacy of cell culture (Karigar and Rao, 2011). Nonetheless, the explicit biochemistry of enzyme-based degradation necessitates an array of catalytic mechanisms owing to the complexity and chemical diversity of pesticides. Oxidoreductases hydrolases and transferases are among the most representative 


\section{A}

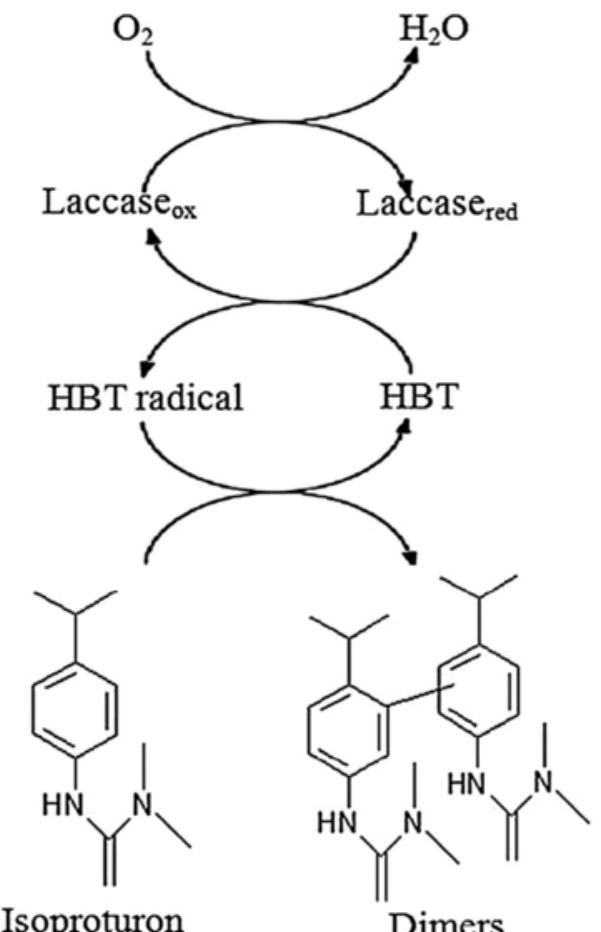

B

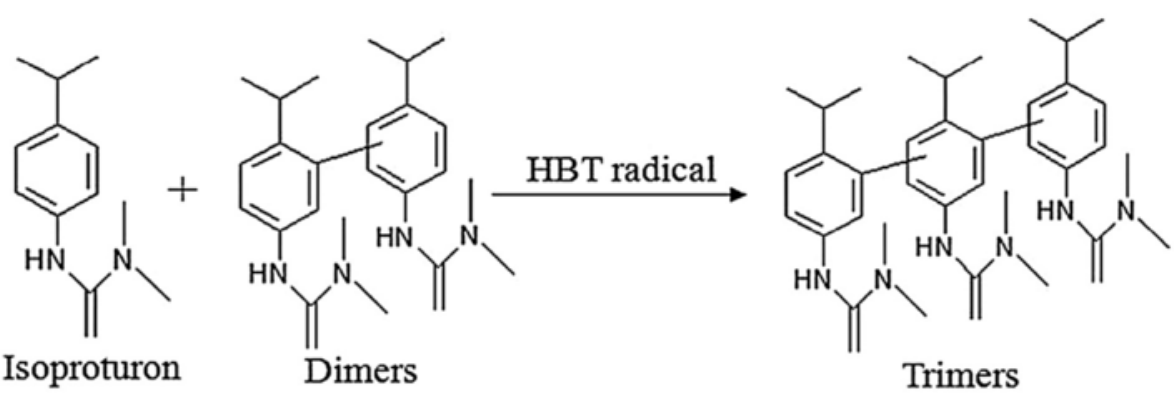

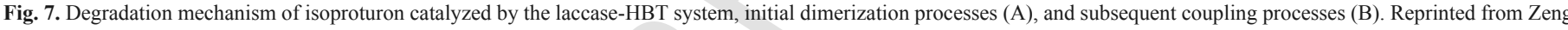

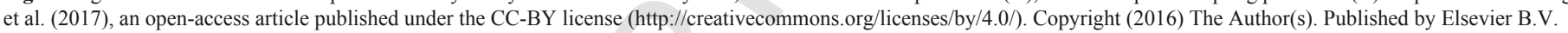

classes of enzymes that have demonstrated an active role in mitigating environmental pollution (Nigam and Shukla, 2015; Maqbool et al., 2016). Application of these enzymes in bioremediation has received substantial attention as a sustainable, selective, and environmentally-friendly alternative to conventional pesticides degradation strategies.

\section{Enzyme-mediated degradation of pesticide}

\subsection{Degradation of pesticides by free laccases without mediators}

In recent years, increasing numbers of studies have been intensively executed on the application of laccase to degrade and detoxify a wide variety of agrochemicals and pesticides with promising results. Zhao et al. (2010) reduced the dichlorodiphenyltrichloroethane (DDT) level in impacted soils using laccase from polypore white rot fungi. They have also been investigated as potent decomposers CP and DCP in an aqueous system. Shi et al. (2016) carried out the toxicity bio-assays in algae cultures incubated with laccase-catalyzed degraded chlorophen (oxCP) and dichlorophen (oxDCP) sub-prod- ucts and found a significant toxicity reduction as evinced by the retrieval of cell growth in laccase-treated organochlorine samples. An extracellular thermo-alkali stabilized crude laccase was produced from the fermented extract of Pseudomonas sp. using potato peel as a bio-waste substrate. The extracted enzyme was purified with a specific activity of $1089.70 \pm 16.8 \mathrm{Umg}^{-1}$ and a molecular mass of $38 \mathrm{kDa}$. The $\mathrm{pH}$ and temperature optima were 9.0 and $80^{\circ} \mathrm{C}$, respectively. The purified enzyme led to $80.56 \%, 45.99 \%, 75.45 \%$, and $81.84 \pm 0.6 \%$ degradation of chlorpyrifos, dichlorophos, monocrotophos, and profenovos pesticides, respectively without the incorporation of any redox mediator (Chauhan and Jha, 2018). Cypermethrin, a group of synthetic pyrethroid insecticides, are excessively applied in agriculture, Horticulture, forestry, households, and public health to manufacture textiles protection and control different pests (Lin et al., 2011; Sharma et al., 2016). Pyrethroid insecticides are also invariably used in vegetable crops and cotton as a substitute to OPPs (Lin et al., 2011), and to combat mosquito-borne and malarial diseases (Nkya et al., 2013). It is regarded as an environmental pollutant due to its prevalent usage, high persistence, and toxicity, which may 
Table 5

Recent degradation studies of various pesticides by laccases immobilized on different support materials.

\begin{tabular}{|c|c|c|c|c|c|}
\hline Source of enzyme & Enzyme support & $\begin{array}{l}\text { Type of } \\
\text { immobilization }\end{array}$ & Performance improvement & Application & Reference \\
\hline $\begin{array}{l}\text { Trametes } \\
\quad \text { versicolor }\end{array}$ & $\begin{array}{l}\text { Acrylate-based } \\
\text { microbeads }\end{array}$ & Covalent binding & $\begin{array}{l}\text { Extended } \mathrm{pH} \text { and temperature } \\
\text { profiles accompanied by a } \\
\text { substantial increase in shelf-life of } \\
\text { the immobilized enzyme than free } \\
\text { enzyme. }\end{array}$ & $\begin{array}{l}\text { The laccase-acetosyringone system results } \\
\text { in complete biodegradation of carbaryl } \\
\text { pesticide and methylene blue. } \\
\text { Insolubilized enzyme lost only } 2 \% \text { and } 8 \% \\
\text { of the initial activity for CP and MB, } \\
\text { biodegradation, respectively, in a fluidized } \\
\text { bed reactor for } 24 \mathrm{~h} \text {. }\end{array}$ & $\begin{array}{l}\text { Bayramoglu } \\
\text { and Arica } \\
(2019)\end{array}$ \\
\hline $\begin{array}{l}\text { Myceliophthora } \\
\text { thermophile }\end{array}$ & $\begin{array}{l}\text { Monodisperse } \\
\text { microspheres of } \\
\text { poly(glycidyl } \\
\text { methacrylate) }\end{array}$ & $\begin{array}{l}\text { Physical } \\
\text { adsorption/ } \\
\text { covalent binding }\end{array}$ & $\begin{array}{l}\text { A large working } \mathrm{pH} \text { and } \\
\text { temperature range. } \\
\text { Significant improvement in } \\
\text { thermal, operational, and storage } \\
\text { stability. }\end{array}$ & $\begin{array}{l}\text { Complete degradation of AZPM after } 1 \mathrm{~h} \text { of } \\
\text { reaction in the presence of } 2,2 \text {-azino-bis- } \\
\text { (3-ethylbenzothiazoline- } 6 \text {-sulfonic acid) as a } \\
\text { mediator }\end{array}$ & $\begin{array}{l}\text { Vera et al. } \\
(2019)\end{array}$ \\
\hline $\begin{array}{l}\text { Coriollopsis } \\
\text { gallica }\end{array}$ & $\begin{array}{l}\text { Mesoporous synthetic } \\
\text { silica foam } \\
\text { nanostructured silicon } \\
\text { foam }\end{array}$ & $\begin{array}{l}\text { Physical } \\
\text { absorption }\end{array}$ & - & $\begin{array}{l}\text { Efficient oxidation of dichlorophen } \\
\text { pesticide, accompanied by a marked } \\
\text { reduction in acute genotoxicity and } \\
\text { apoptotic effects. }\end{array}$ & $\begin{array}{l}\text { Vidal- } \\
\text { Limon et al. } \\
(2018)\end{array}$ \\
\hline- & $\begin{array}{l}\text { Activated bagasse/ } \\
\text { cellulose nanofibers }\end{array}$ & Covalent binding & $\begin{array}{l}\text { Catalytic activity over a } \mathrm{pH} \text { range } \\
\text { from } 6 \text { to } 10 \text { and up to } 80{ }^{\circ} \mathrm{C} \text {. } \\
\text { Retained more than } 60 \% \text { of } \\
\text { activity after } 15 \text { cycles. } \\
\text { High stability preserving } 75 \% \text { of } \\
\text { its relative activity after } 45 \text { days. }\end{array}$ & $\begin{array}{l}\text { The biocatalyst achieved } 78.71 \% \text {, and } 100 \% \\
\text { trifluralin degradation efficiency in } 24 \mathrm{~h} \text { in } \\
\text { the presence of catechol, and humic } \\
\text { monomers, guiacol respectively, as } \\
\text { mediators. }\end{array}$ & $\begin{array}{l}\text { Bansal et al. } \\
(2018)\end{array}$ \\
\hline $\begin{array}{l}\text { Trametes } \\
\quad \text { versicolor }\end{array}$ & $\begin{array}{l}\text { Chitosan-coated and } \\
\text { carbodiimide surface } \\
\text { modified magnetic iron } \\
\text { nanoparticles }\end{array}$ & Covalent binding & $\begin{array}{l}\text { Significant increase in the stability } \\
\text { against } \mathrm{pH} \text { and temperature } \\
\text { variations. } \\
\text { Retained } 95 \% \text { of its activity after } \\
\text { five consecutive cycles. }\end{array}$ & $\begin{array}{l}\text { Under optimal conditions of } \mathrm{pH} 7.0 \text { and } \\
60^{\circ} \mathrm{C} \text {, the laccase-coupled MNPs showed } \\
\text { excellent efficiency to degrade higher than } \\
99 \% \text { chlorpyrifos in } 12 \mathrm{~h} .\end{array}$ & $\begin{array}{l}\text { Das et al. } \\
(2017)\end{array}$ \\
\hline Aspergillus sp. & Mesoporous silica & Cross-linking & $\begin{array}{l}\text { Significantly improved } \\
\text { repeatability of immobilized } \\
\text { laccase as compared with the free } \\
\text { enzyme }\end{array}$ & $\begin{array}{l}\text { The immobilized biocatalyst achieved } 42.28 \\
\text { and } 15.93 \% \text { removal ratio and the } \\
\text { degradation ratio of } 2,4 \text {-dichlorophenol } \\
\text { pesticide, respectively. }\end{array}$ & $\begin{array}{l}\text { Yang et al. } \\
\text { (2016a) }\end{array}$ \\
\hline $\begin{array}{l}\text { Trametes } \\
\text { versicolor }\end{array}$ & $\begin{array}{l}\text { Tubular mesoporous } \\
\text { silica containing } \\
\text { ultrasmall } \\
\text { superparamagnetic iron } \\
\text { oxide nanoparticles }\end{array}$ & Cross-linking & $\begin{array}{l}\text { Retained } 20.8 \% \text { of catalytic } \\
\text { efficiency after seven continuous } \\
\text { cycles. }\end{array}$ & $\begin{array}{l}45.6 \% \text { degradation of methoxychlor } \\
\text { pesticide in aqueous and reverse micelle } \\
\text { environments by the immobilized enzyme. }\end{array}$ & $\begin{array}{l}\text { Yang et al. } \\
\text { (2016b) }\end{array}$ \\
\hline
\end{tabular}

cause harmful effects to non-target entities and several ecosystems. Laccase and esterase play a noteworthy role in the biodegradation and detoxification of these synthetic pyrethroid insecticides in the environment owing to their specific nature.

\subsection{Degradation of pesticides by laccase-mediators system}

Degradation studies of various pesticides by free laccases in the presence of different redox mediators are summarized in Table 4. Despite the obvious efficacy of laccase-mediator systems to decompose recalcitrant aromatic compounds, the use of mediator-based enzyme systems is generally hampered by the economic cost of synthetic mediators and the generation of toxic species (Cañas and Camarero, 2010). Mediators of natural origin, especially the lignin-related phenolic compounds are excellent and environmentally-friendly alternatives to overcome this issue (Grijalva-Bustamante et al., 2016). Kupski et al. (2019), for the first time, developed an optimized laccase-mediator system to remove different pesticides including bentazone, carbofuran, clomazone, diuron, pyraclostrobin, and tebuconazole in the aqueous samples. Among seven redox-mediating compounds screened, i.e., 2,2' -azino-bis-(3-ethylbenzothiazoline-6-sulfonate) (ABTS), caffeic acid, chlorogenic acid, $p$-coumaric acid, ferulic acid, gallic acid, protocatechuic acid, and vanillin, the laccase-vanillin system showed the highest removal efficiency (77\%) of pesticides. Ashe et al. (2016) evaluated the removal efficiency of four organic contaminants (oxybenzone, pentachlorophenol, atrazine, and naproxen) by laccase with different mediators i.e. ABTS, (1-hydroxybenzotriazole (HBT), $N$-hydroxyphthalimide (HPI), 2,2,6,6-tetramethylpiperidinyloxyl (TEMPO), $\quad$ syringaldehyde $\quad$ (SA), violuric acid (VA), and vanillin (VAN). Among these mediators, ABTS, HBT, and VA accomplished the highest removal of environmental pollutants. The herbicide isoproturon was effectively removed by Zeng et al. (2017) using six mediators such as acetosyringone, ABTS, HBT, SA, VA, and VAN. In contrast to natural mediators, the synthetic ones were found more effective in laccase-assisted catalytic degradation of isoproturon. According to literature reports, mediators follow three major mechanisms for substrate oxidation includes electron transfer, hydrogen atom transfer, and ionic mechanisms. ABTS follows electron transfer, whereas vanillin uses hydrogen atom transfer (Ashe et al., 2016). Trovaslet-Leroy et al. (2010) reported the effective degradation and detoxification of organophosphorus compounds and nerve agents O-ethyl S-[N,N-diisopropylaminoethyl] methylphospho nothiolate (VX), O-ethyl-S-[2-(diisopropylamino)ethyl] phenylphosphonothioate $(\mathrm{PhX})$ and $\mathrm{RVX}$ by a laccase from Trametes versicolor in the presence of ABTS as a redox mediator. Among nine tested redox mediators, acetosyringone and syringaldehyde played a significant role in the destruction of halogenated pesticide by the ligninolytic enzymes. Under in vitro conditions, the laccase-mediator system containing ABTS, Tween 80 , and $\mathrm{Mn}^{2+}$ as mediators result in the degradation of glyphosate pesticide by $40.9 \%, 90.1 \%$, and $62.8 \%$, respectively, after $24 \mathrm{~h}$ of incubation at $35^{\circ} \mathrm{C}$ and $150 \mathrm{rpm}$ (Pizzul et al., 2009).

Isoproturon is a kind of phenylurea herbicide with a wide spectrum of agricultural applications to limit the growth of weeds including silky bent-grass, ryegrass, and many broadleaf species in winter and spring wheat (Castillo et al., 2001). However, its use produces a potentially carcinogenic intermediate that adversely influences the environment, particularly marine invertebrates, microbes, and al- 
<smiles>COc1ccc(CC(Cl)C(Cl)(Cl)C(C)(Cl)Cl)cc1</smiles><smiles>COc1cccc(C(C)(C)C)c1</smiles>

\section{Scheme 2}

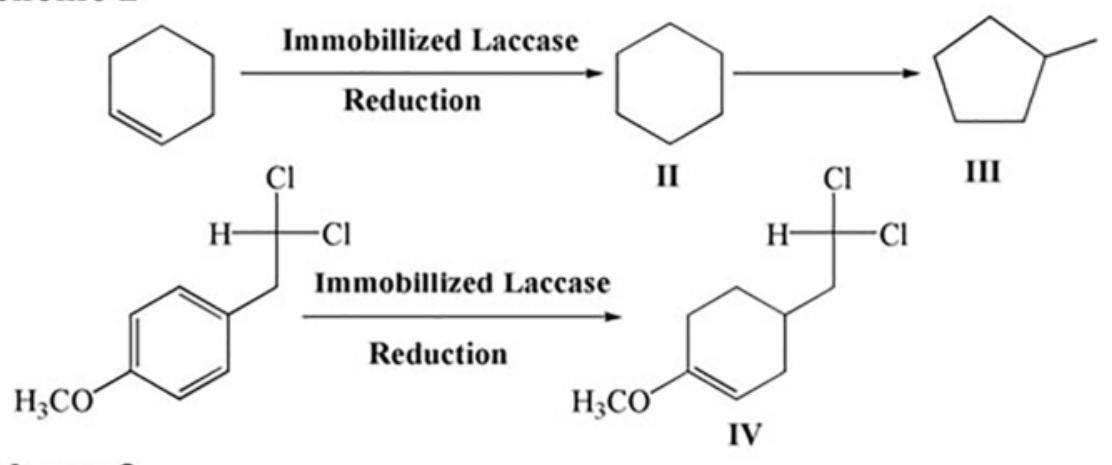

\section{Scheme 3}

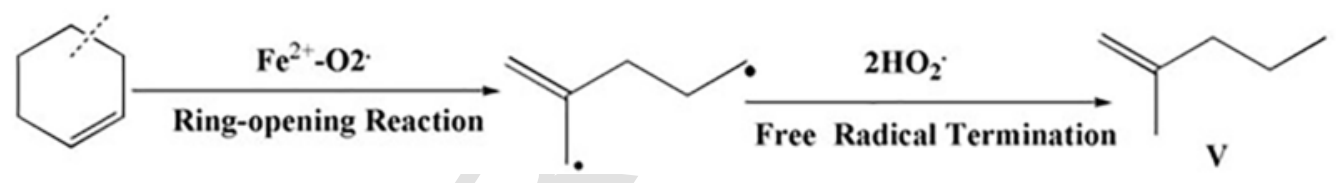

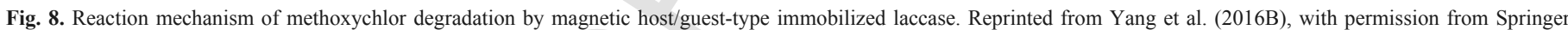
Nature. Copyright (2016) Springer-Verlag Berlin Heidelberg.

gae. Around $3300 \mathrm{t}$ of this herbicide was applied to 3.0 million hectares of agronomic land in the UK in 1997. It has been detected as a contaminant in streams, rivers, marine, and ground waters because of its extensive and widespread practice in modern agriculture, around the globe (Sørensen et al., 2003). Considering its negative ecological impacts, it is highly desirable to eliminate this herbicide from wastewater. Zeng et al. (2017) examined the degradation of isoproturon using $T$. versicolor laccase using HBT as a redox mediator. Without a mediator, isoproturon was hardly disintegrated by laccase alone due to the presence of robust withdrawing electron group in its chemical organization. However, the LMS increased the degradation efficiency, leading to the complete degradation of isoproturon within $24 \mathrm{~h}$ in the presence of HBT. Optimal degradation occurred at an acidic $\mathrm{pH}$ and $50^{\circ} \mathrm{C}$, and incorporation of metal ions $\mathrm{Cu}^{2+}, \mathrm{Cd}^{2+}$, and $\mathrm{Zn}^{2+}$ promoted elimination rate by the laccase-HBT system. Addition of PEG can also enhance the herbicide degradation efficacy of the laccase-HBT system by improving the laccase stability. The possi- ble mechanism of isoproturon degradation by the laccase-HBT system might be ascribed to oligomerization of oxidized isoproturon through the radical-radical coupling. Fig. 7 represents the speculated oligomerization processes for the degradation of isoproturon (Zeng et al., 2017). Under the optimum conditions, laccase produced from Trametes versicolor has shown a great ability for the degradation of five selected pesticides, i.e. atrazine, chlorothalonil, chlorpyrifos, isoproturon, and pyrimethanil in the presence of mediator acetosyringone, vanillin, violuric acid, and HBT. The enzyme was stable at $\mathrm{pH}$ and a temperature range from 5.0 to 7.0 and 25 to $30^{\circ} \mathrm{C}$, respectively. The degradation efficiencies of isoproturon and pyrimethanil were considerably faster as compared to atrazine, chlorothalonil, and chlorpyrifos. Results showed that isoproturon and pyrimethanil were completely decomposed within after $24 \mathrm{~h}$, whereas the other three pesticides were $90 \%$ degrade even after 8 days of treatment (Jin et al., 2016). Finally, laccase-treated and transformed products showed significantly lower eco-toxicity to green algae as compared to the na- 

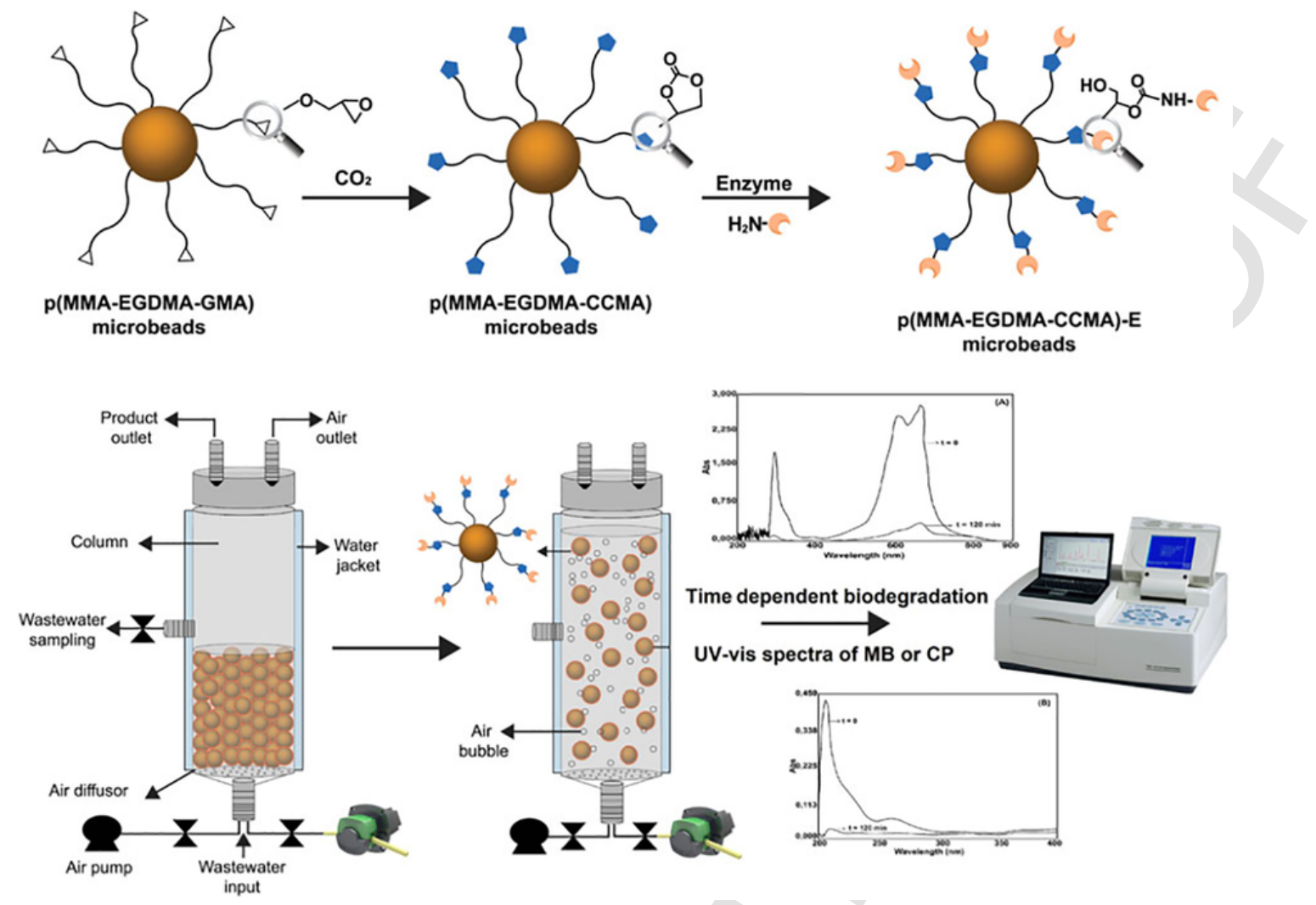

Fig. 9. Schematic representation of bioremediation of pollutants in the reactor system. Reprinted from Bayramoglu and Arica (2019), with permission from Taylor \& Francis. Copyright (2019) Taylor \& Francis Group, LLC.

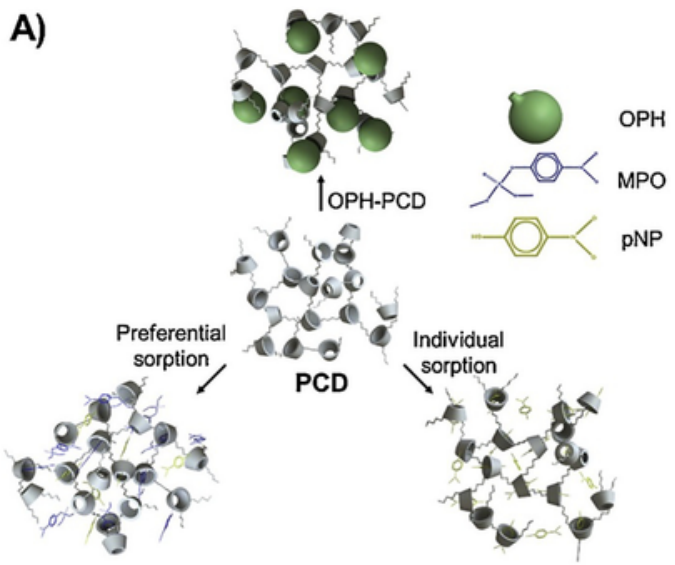

B)

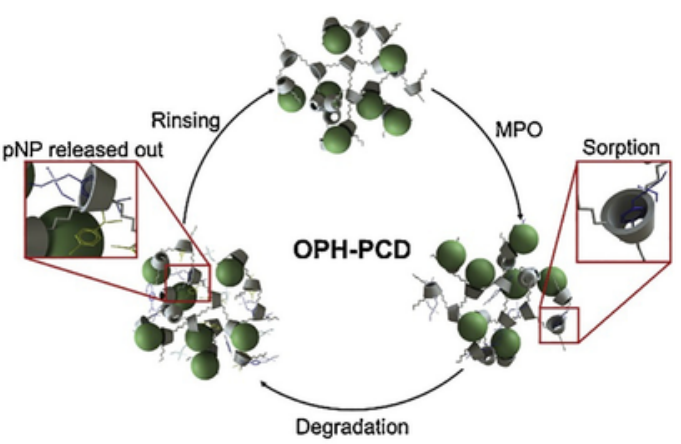

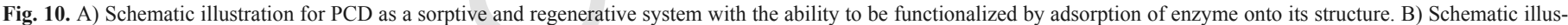

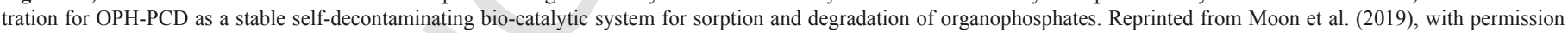
from Elsevier. Copyright (2018) Elsevier B.V.

tive isoproturon indicating the usefulness of the LMS to remediate herbicide-containing industrial wastewater.

\subsection{Degradation of pesticides by immobilized laccases}

Some recent degradation studies of various pesticides by laccases immobilized on different support materials are summarized in Table 5. To achieve enhanced biodegradation of dichlorophen, Vidal-Limon et al. (2018) immobilized Coriollopsis gallica laccase on mesoporous synthetic silica foam nanostructured silicon foam (MSU-F) by physi- cal absorption to develop a hybrid nanomaterial (laccase-MSU-F). High enzyme adsorption $(7 \mu \mathrm{M} / \mu \mathrm{g}$ MSU-F) on the nanocomposite suggest that enzyme stabilization into MSU-F internal pores could be interceded by noncovalent interactions (such as electrostatic interactions). The newly-synthesized laccase-MSU-F hybrid nanocomposite efficiently oxidized the dichlorophen pesticide, accompanied by a marked reduced in acute genotoxicity and apoptotic effects. Moreover, laccase-MSU-F nanomaterial diminished the onset of endocrine disruption by decreasing the dichlorophen affinity for steroid hormone nuclear receptors (NRs). The authors also found that silica- 
based mesoporous MSU-F provides a potential "protecting effect" following laccase immobilization. Therefore, mesoporous nanocomposites can be scaled up to several grams due to its high loading capability. Recently, laccase from Myceliophthora thermophile (MtL) was immobilized onto monodisperse microspheres of poly(glycidyl methacrylate) (PGMA) and applied for azinphos-methyl (AZPM) biodegradation. The immobilized biocatalytic system demonstrated a wide-working $\mathrm{pH}$ and temperature range of optimal activity and significantly improved the thermal, operational, and storage stability. It achieved the complete degradation of AZPM after $1 \mathrm{~h}$ of reaction in the presence of ABTS as a mediator (Vera et al., 2019).

Trifluralin is a moderately persistent and toxic agricultural herbicide that is resilient to natural degradation technologies (Fragoeiro and Magan, 2005). Among the various pesticide treatment strategies, advanced oxidation processes (AOPs) have been largely attempted for trifluralin decomposition, which include photolysis in presence of UV and $\mathrm{H}_{2} \mathrm{O}_{2}$ (Chelme-Ayala et al., 2010a), hydroxyl radicals (Le Person et al., 2007), ozonation (Chelme-Ayala et al., 2010b), and photo-assisted degradation using $\mathrm{SnO}_{2}$-doped $\mathrm{Cu}_{2} \mathrm{O}$ crystals (Du et al., 2010). However, some drawbacks such as the high operating cost and undesirable intermediates generation hinder the use of these processes. Bio-degradation of trifluralin pesticide using extracellular fungal laccase is a preferential option and has been assessed in previous studies (Lafi and Al-Qodah, 2006). Bansal et al. (2018) carried out the immobilization of laccase on activated bagasse/cellulose nanofibers (CNFs)-based carried support with $85 \%$ immobilization yield. CNFs were extracted from a readily available agro-waste, bagasse using a cost-efficient and eco-friendly process. Polyethyleneimine (PEI) and glutaraldehyde (GLU) were used to introduce the amine group, and aldehyde through a Schiff base reaction during the immobilization process. The immobilized biocatalyst showed catalytic performance over a large $\mathrm{pH}$ range from 6 to 10 and investigated to be active up to $80^{\circ} \mathrm{C}$. The immobilized enzyme maintained more than $60 \%$ of the initial activity after 15 successive reaction cycles. It also exhibited high stability and retained $75 \%$ of its relative activity after 45 days. Finally, the practical efficacy of bagasse nano cellulose-grafted laccase was verified by investigating its capability to degrade trifluralin. Notably, the grafted biocatalyst achieved $78.71 \%$, and $100 \%$ degradation efficiency in $24 \mathrm{~h}$ in the presence of catechol, and humic monomers, guiacol respectively, as mediators.

Chlorpyrifos is an extensively used insecticide since 1965 for household and agricultural pest control. It can contaminate the site up to $24 \mathrm{~km}$ away from the point of applications, leading to undesirable environmental effects, and resultantly, necessitating its judicious remediation (Singh et al., 2004). The degradation of chlorpyrifos pesticide was investigated using laccase incorporated on chitosan coated, and carbodiimide surface modified magnetic iron nanoparticles (CENPs) with size ranged from 10 to $15 \mathrm{~nm}$. The developed nanobiocatalyst was used for the degradation of chlorpyrifos in a batch reaction for $12 \mathrm{~h}$ under constant shaking. Under optimal conditions of $\mathrm{pH} 7.0$ and $60^{\circ} \mathrm{C}$, the laccase-coupled MNPs showed excellent efficiency to degrade higher than $99 \%$ chlorpyrifos in $12 \mathrm{~h}$. After immobilization, the overall activity of the enzyme was decreased than that to the free enzyme. Moreover, the nanobiocatalytic system possessed good recycling potential and demonstrated $95 \%$ of its original activity after five consecutive cycles. Based on gas chromatography-mass spectrometry (GC-MS) analysis, two main degradation products, i.e. 1,2 benzene dicarboxylic acid, bis(2-methyl propyl) ester and 2,4-bis(1,1 dimethylethyl) phenol were noticed in the treated extract (Das et al., 2017). Yang et al. (2016a) utilized glutaraldehyde-activated mesoporous silica having the large specific surface area for the immobilization of laccase by a cross-linking approach. After ing the experiments, the optimal enzyme immobilization occurred under the processing conditions of $\mathrm{pH} 5.4,25^{\circ} \mathrm{C}, 4 \% \mathrm{GLU}$ and $0.2 \mathrm{mg} /$ $\mathrm{mL}$ laccase solution. The optimally immobilized biocatalyst was applied for the degradation and removal of a 2,4-dichlorophenol pesticide under different degradation environments. Results showed a removal and degradation ratio of 42.28 and $15.93 \%$, respectively, by the cross-linked biocatalyst at $\mathrm{pH} 5.4$, and $30^{\circ} \mathrm{C}$ using $0.1 \mathrm{~g}$ of immobilized laccase. With reference to the soluble laccase, the recycling ability of the insolubilized enzymes was substantially increased. In another study, the same research group carried out the degradation of an organochlorine pesticide methoxychlor in aqueous media. Reports have demonstrated that methoxychlor can exert undesirable consequences by altering the secretion of pituitary follicle-stimulating hormone, and thus affect the reproductive system of both the male and female. In order to degrade methoxychlor, they constructed a nanobiocatalytic system by cross-linking laccase enzyme into superparamagnetic iron oxide nanoparticles, and the influences of various variables on pesticide removal were examined. The immobilized biocatalyst result in $45.6 \%$ bio-degradation of pesticide along with retention of $20.8 \%$ of its initial catalytic activity after seven repeated reaction cycles under the optimized conditions. Supplementation of ABTS to the system considerably increased the elimination efficiency. A plausible mechanism of methoxychlor degradation was speculated based on the intermediate metabolites detected by GC-MS and NMR analyses (Fig. 8) (Yang et al., 2016B).

Of most recent, Bayramoglu and Arica, (2019) synthesized the cross-linked poly(glycidyl methacrylateethyleneglycole dimethacrylate-glycidyl methacrylate), p(MMAEGMA- GMA) microbeads by suspension polymerization followed by the replacement of epoxy groups of the terpolymer with the cyclic carbonate groups under $\mathrm{CO}_{2}$ atmosphere (i.e., p(MMA-EGMA-CCMA)). After characterization, the resulting both p(MMA-EGMA-GMA) and p(MMA-EGMA-CCMA) microbeads were subjected to laccase immobilization. p(MMA-EGMA-CCMA) microbeads-immobilized laccase can be executed at low temperature and showed expanded $\mathrm{pH}$ and temperature ranges accompanied by a substantial increase in shelf-life than free enzyme. The synthesized biocatalytic system was applied for the biodegradation and elimination of two kinds of micro-pollutants including carbaryl pesticide (CP) and methylene blue (MB) dye in the presence of various mediators. In contrast to $71 \%$ and $63 \%$ degradation of $\mathrm{CP}$ and $\mathrm{MB}$, respectively, without the use of a mediator, the laccase-acetosyringone system caused complete biodegradation of both micro-pollutants. Furthermore, the insolubilized enzyme dropped only $2 \%$ and $8 \%$ of the initial activity for biodegradation of $\mathrm{CP}$ and $\mathrm{MB}$, respectively, when operated in a fluidized bed reactor for $24 \mathrm{~h}$. Fig. 9 presents the diagrammatic configuration of the fluidized bed reactor system employed for the degradation of micropollutants (Bayramoglu and Arica, 2019).

\subsection{Degradation of pesticides by other immobilized enzymes}

Microbial phosphotriesterases are very interesting enzymes for pesticides degradation and detoxification because of their higher biocatalytic efficacy and wider substrate specificity (Porzio et al., 2007). Vitola et al. (2019) developed a continuous biocatalytic membrane reactor for pesticide and organophosphate paraoxon decontamination using a triple mutant of the thermostable phosphotriesterase obtained from the Sulfolobus solfataricus. For this, various phosphotriesterases were covalently coupled to different polymeric membranes such as polyvinylidene fluoride, polyethersulfon. The enzymes displayed noteworthy stability at varying $\mathrm{pH}(5-9)$ and temperature ranges (10-100 $\left.{ }^{\circ} \mathrm{C}\right)$ owing to their hyperthermophilic origin. High degradation 
of paraoxon pesticide (about 90\%) and durable stability of one year was observed by the hydrophilic membranes-based newly constructed biocatalytic system. This increased stability allows the biocatalyst remaining active over longer periods, improving storage, and overcoming the deactivation issues of the typical native enzyme. In contrast, the free enzyme completely lost its activity within a few months in a batch system. Halloysite nanotubes (HNT), a kind of kaolin clay, is regarded as promising support for biomolecules/enzymes immobilization owing to its larger specific surface area, low-cost, abundance, biocompatibility, and mechanical and chemical stability. In order to exploit its use as enzyme immobilization carrier, Fan et al. (2018) proposed two strategies for embedding and entrapping C. fumago chloroperoxidase (CPO) enzyme on outer as well as an inner wall of HNT. In comparison to the free enzyme, the thermal steadiness and resistance to organic solvents of the immobilized enzyme were substantially enhanced. The immobilized CPO retained $87.63 \%$ of its original activity after $1 \mathrm{~h}$ heating at $80^{\circ} \mathrm{C}$, whereas only $11.66 \%$ activity was recorded for the free $\mathrm{CPO}$ under identical conditions. Free dropped all its activity by incubation at $90^{\circ} \mathrm{C}$ for $90 \mathrm{~min}$, while the supported biocatalyst still exhibited $40.3 \%$ activity. Moreover, immobilized enzyme showed almost no activity loss in the presence of various organic solvents including acetonitrile, ethyl acetate, $N, N$-dimethyl formamide, and methanol, but free CPO displayed only $38.2 \%, 41.6 \%$, and $23.5 \%$ of its original activity in acetonitrile, ethyl acetate, and methanol, respectively, and completely inactivated in $N, N$-dimethyl formamide in the same conditions. Finally, the immobilized biocatalytic system was found to be very efficient for degrading isoproturon in wastewater samples. It caused a complete degradation of isoproturon within 10 min that indicated its noteworthy practical implementation in remediating pesticide-harboring wastewater. Moon et al. (2019) developed a non-toxic novel bio-catalytic material by immobilizing organophosphorus hydrolase $(\mathrm{OPH})$ onto poly- $\beta$-cyclodextrin $(\mathrm{PCD})$ as a new sorptive reinforced self-decontaminating material for the intoxication of organophosphate (Fig. 10). The synthesized OPH-coated PCD not only provided support for encapsulating enzyme but also adsorbed methyl paraoxon (MPO) used as a simulant in a host-guest inclusion complex formation. Sorption profile for PCD demonstrated an inclination towards the more hydrophobic MPO against para-nitrophenol (pNP). Results revealed 1.7 times higher sorption capacity of MPO with PCD relative to pNP. As compared to the free enzyme, the reaction rate was $23 \%$ decreased by immobilized OPH-PCD. However, the bio-catalytic system presented complete hydrolysis (100\%) of MPO into $\mathrm{pNP}$ for a period of $24 \mathrm{~h}$ in a continuous packed bed reactor with profound stability and reproducibility of the enzyme. The fast, reactive nature and durable stability render the resulting system as a promising approach for the detection and neutralization of hazardous chemical warfare agents/nerve agents and decontamination of the environment.

\section{Concluding remarks and outlook}

Pesticide contamination has become a global problem nowadays that affects not only the ecosystems (soil and water resources) but also the health of humans, animals, microorganisms, and plants. Therefore, it is of great significance to propose green, sustainable, and environmentally friendly strategies for complete remediation of pesticides from the polluted milieus. A comprehensive and up-to-date overview of the literature presented herein highlights the potential of enzymes in biodegradation and detoxification of a range of agrochemicals and pesticides. Among different kinds of pesticide-degrading enzymes, laccases are of exceptional interest due to high efficiency, specificity, eco-sustainability, and wide-ranging sub- strates. Laccases catalyzed the oxidation of aromatic compounds containing a phenolic functional group. However, this degradation range can be expanded towards non-phenolic substrates by incorporating a suitable redox mediator. Furthermore, it is worthy of mentioning that the pesticide removal and degradation efficiency of biocatalysts can be significantly enhanced when they were applied in the immobilized forms. Several reports have documented the ameliorated ability of the immobilized form of the laccases to degrade and bio-transform a variety of toxic pollutants present in industrial dyes, personal care products, and pesticides/herbicides. Increase in stability, reusability, reduction of product inhibition, enhanced activity, specificity, and easier product separation are among the most desirable advantages of immobilization to develop biocatalysts for continuous systems in industrial bioprocessing. In addition to isolating and characterize new pesticide-degrading enzymes, there is also a need to scrutinize the environmental fates and toxicity of the metabolites generated as a result of pesticides mineralization. Moreover, large scale and in-depth assessment of enzyme-mediated degradation of pesticides are required, as observed in laboratories, under in situ field conditions to appraise the success of enzymatic bioremediation. Future studies should be carried out to characterize the genetic basis of the biodegradation of the pesticide by utilizing advanced omics-based strategies to identify the genes, and intermediate metabolites related to pesticides mineralization. A comprehensive understanding of the long-term ecological and economic impacts concerning enzyme applicability for the remediation of pesticides/herbicides is crucial to apprehend full potential and sustainability of immobilized enzyme technology.

\section{Declaration of competing interest}

The authors declare that they have no conflict of interest.

\section{Acknowledgment}

All authors are grateful to their representative universities and/or institutes for providing literature services.

\section{References}

Aamir, M., Khan, S., Li, G., 2018. Dietary exposure to HCH and DDT congeners and their associated cancer risk based on Pakistani food consumption. Environ. Sci. Pollut. Res. 25 (9), 8465-8474.

Ahmed, G., Anawar, H.M., Takuwa, D.T., Chibua, I.T., Singh, G.S., Sichilongo, K., 2015. Environmental assessment of fate, transport and persistent behavior of dichlorodiphenyltrichloroethanes and hexachlorocyclohexanes in land and water ecosystems. Int. J. Environ. Sci. Technol. 12 (8), 2741-2756.

Ahmed, I., Iqbal, H.M., Dhama, K., 2017. Enzyme-based biodegradation of hazardous pollutants-an overview. J. Exp. Biol. Agric. Sci 5 (4), 402-411.

Ali, N., Khan, S., Khan, M.A., Waqas, M., Yao, H., 2019. Endocrine disrupting pesticides in soil and their health risk through ingestion of vegetables grown in Pakistan. Environ. Sci. Pollut. Res. 1-13.

Andleeb, S., Jiang, Z., ur Rehman, K., Olajide, E.K., Ying, Z., 2016. Influence of soil $\mathrm{pH}$ and temperature on atrazine bioremediation. Journal of Northeast Agricultural University (English Edition) 23 (2), 12-19.

Antecka, K., Zdarta, J., Siwińska-Stefańska, K., Sztuk, G., Jankowska, E., Oleskowicz-Popiel, P., Jesionowski, T., 2018. Synergistic degradation of dye wastewaters using binary or ternary oxide systems with immobilized laccase. Catalysts 8 (9), 402 .

Asgher, M., Shahid, M., Kamal, S., Iqbal, H.M.N., 2014. Recent trends and valorization of immobilization strategies and ligninolytic enzymes by industrial biotechnology. J. Mol. Catal. B Enzym. 101, 56-66.

Ashe, B., Nguyen, L.N., Hai, F.I., Lee, D.J., Van De Merwe, J.P., Leusch, F.D., Price, W.E., Nghiem, L.D., 2016. Impacts of redox-mediator type on trace organic contaminants degradation by laccase: degradation efficiency, laccase stability and effluent toxicity. Int. Biodeterior. Biodegradation 113, 169-176.

Bansal, M., Kumar, D., Chauhan, G.S., Kaushik, A., 2018. Preparation, characterization and trifluralin degradation of laccase-modified cellulose nanofibers. Materials Science for Energy Technologies 1 (1), 29-37. 
Barbieri, M.V., Postigo, C., Guillem-Argiles, N., Monllor-Alcaraz, L.S., Simionato, J.I., Stella, E., ... de Alda, M.L., 2019. Analysis of 52 pesticides in fresh fish muscle by QuEChERS extraction followed by LC-MS/MS determination. Sci. Total Environ. 653, 958-967.

Barragan-Huerta, B.E., Costa-Pérez, C., Peralta-Cruz, J., Barrera-Cortés, J., Esparza-García, F., Rodríguez-Vázquez, R., 2007. Biodegradation of organochlorine pesticides by bacteria grown in microniches of the porous structure of green bean coffee. Int. Biodeterior. Biodegradation 59 (3), 239-244.

Barrios-Estrada, C., de Jesús Rostro-Alanis, M., Muñoz-Gutiérrez, B. D., Iqbal, H. M. Kannan, S., \& Parra-Saldívar, R. (2018). Emergent contaminants: endocrine disruptors and their laccase-assisted degradation-a review. Sci. Total Environ., 612, 1516-1531.

Bayramoglu, G., Arica, M.Y., 2019. Biodegradation of methylene blue and carbaryl by Trametes versicolor laccase preparations in the presence of a mediator compound. Journal of Macromolecular Science, Part A - Pure and Applied Chemistry 56, $277-285$

Bilal, M., Iqbal, H.M., 2019. Chemical, physical, and biological coordination: an inter play between materials and enzymes as potential platforms for immobilization. Coord. Chem. Rev. 388, 1-23.

Bilal, M., Iqbal, H.M., 2019. Tailoring multipurpose biocatalysts via protein engineering approaches: a review. Catal. Lett. 149 (8), 2204-2217.

Bilal, M., Asgher, M., Parra-Saldivar, R., Hu, H., Wang, W., Zhang, X., Iqbal, H.M., 2017. Immobilized ligninolytic enzymes: an innovative and environmental responsive technology to tackle dye-based industrial pollutants-a review. Sci. Total Environ. 576, 646-659.

Bilal, M., Rasheed, T., Zhao, Y., Iqbal, H.M., Cui, J., 2018. "Smart" chemistry and its application in peroxidase immobilization using different support materials. Int. J. Biol. Macromol. 119, 278-290.

Bilal, M., Rasheed, T., Iqbal, H.M.N., Yan, Y., 2018. Peroxidases-assisted removal of environmentally-related hazardous pollutants with reference to the reaction mechanisms of industrial dyes. Sci. Total Environ. 644, 1-13.

Bilal, M., Iqbal, H.M., Shuqi, G., Hu, H., Wang, W., Zhang, X., 2018. State-of-the-art protein engineering approaches using biological macromolecules: a review from immobilization to implementation view point. Int. J. Biol. Macromol. 108 893-901.

Bilal, M., Rasheed, T., Zhao, Y., Iqbal, H.M., 2019. Agarose-chitosan hydrogel-immobilized horseradish peroxidase with sustainable bio-catalytic and dye degradation properties. Int. J. Biol. Macromol. 124, 742-749.

Brouwer, M., Huss, A., van der Mark, M., Nijssen, P.C., Mulleners, W.M., Sas, A.M., van Laar, T., de Snoo, G.R., Kromhout, H., Vermeulen, R.C., 2017. Environmental exposure to pesticides and the risk of Parkinson's disease in the Netherlands. Environ. Int. 107, 100-110

Cañas, A.I., Camarero, S., 2010. Laccases and their natural mediators: biotechnological tools for sustainable eco-friendly processes. Biotechnol. Adv. 28 (6), 694-705.

Carvalho, F.P., 2017. Pesticides, environment, and food safety. Food and Energy Security $6(2), 48-60$.

Castillo, M.D., von Wirén-Lehr, S., Scheunert, I., Torstensson, L., 2001. Degradation of isoproturon by the white rot fungus Phanerochaete chrysosporium. Biol. Fertil. Soils 33 (6), 521-528.

Cederlund, H., Börjesson, E., Lundberg, D., Stenström, J., 2016. Adsorption of pesticides with different chemical properties to a wood biochar treated with heat and iron. Water Air Soil Pollut. 227 (6), 203.

Chauhan, P.S., Jha, B., 2018. Pilot scale production of extracellular thermo-alkali stable laccase from Pseudomonas sp. S2 using agro waste and its application in organophosphorus pesticides degradation. J. Chem. Technol. Biotechnol. 93 (4), $1022-1030$

Chelme-Ayala, P., El-Din, M.G., Smith, D.W., 2010. Degradation of bromoxynil and trifluralin in natural water by direct photolysis and UV plus $\mathrm{H} 2 \mathrm{O} 2$ advanced oxidation process. Water Res. 44 (7), 2221-2228.

Chelme-Ayala, P., El-Din, M.G., Smith, D.W., 2010. Kinetics and mechanism of the degradation of two pesticides in aqueous solutions by ozonation. Chemosphere 78 (5), 557-562

Das, A., Singh, J., Yogalakshmi, K.N., 2017. Laccase immobilized magnetic iron nanoparticles: fabrication and its performance evaluation in chlorpyrifos degradation. Int. Biodeterior. Biodegradation 117, 183-189.

Du, Y., Zhang, N., Wang, C., 2010. Photo-catalytic degradation of trifluralin by SnO2-doped Cu2O crystals. Catal. Commun. 11 (7), 670-674.

Fan, X., Hu, M., Li, S., Zhai, Q., Wang, F., Jiang, Y., 2018. Charge controlled immobilization of chloroperoxidase on both inner/outer wall of NHT: improved stability and catalytic performance in the degradation of pesticide. Appl. Clay Sci. 163, 92-99.

Feng, Y., Zhong, L., Bilal, M., Tan, Z., Hou, Y., Jia, S., Cui, J., 2019. Enzymes@ZIF-8 nanocomposites with protection nanocoating: stability and acid-resistant evaluation. Polymers 11 (1), 27.
Fragoeiro, S., Magan, N., 2005. Enzymatic activity, osmotic stress and degradation of pesticide mixtures in soil extract liquid broth inoculated with Phanerochaete chrysosporium and Trametes versicolor. Environ. Microbiol. 7 (3), 348-355. ,. Sci. Rep.

Gereslassie, T., Workineh, A., Atieno, O., Wang, J., 2019. Determination of occurrences, distribution, health impacts of organochlorine pesticides in soils of Central China. Int. J. Environ. Res. Public Health 16 (1), 146.

Ghanem, I., Orfi, M., Shamma, M., 2007. Biodegradation of chlorphyrifos by Klebsiella sp. isolated from an activated sludge sample of waste water treatment plant in Damascus. Folia Microbiol. 52 (4), 423-427.

Gopalan, N.K., Chenicherry, S., 2018. Fate and distribution of organochlorine insecticides (OCIs) in Palakkad soil, India. Sustainable Environment Research 28 (4), $179-185$.

Grijalva-Bustamante, G.A., Evans-Villegas, A.G., del Castillo-Castro, T., Castillo-Ortega, M.M., Cruz-Silva, R., Huerta, F., Morallón, E., 2016. Enzyme mediated synthesis of polypyrrole in the presence of chondroitin sulfate and redox mediators of natural origin. Mater. Sci. Eng. C 63, 650-656.

Hayatsu, M., Mizutani, A., Hashimoto, M., Sato, K., Hayano, K., 2001. Purification and characterization of carbaryl hydrolase from Arthrobacter sp. RC100. FEMS Microbiol. Lett. 201 (1), 99-103.

He, Z., Zhang, A., Li, Y., Song, S., Liu, Z., Chen, J., Xu, X., 2011. Chlorophene degradation by combined ultraviolet irradiation and ozonation. J. Environ. Sci. Health A 46 (1), 1-8.

Idowu, G.A., 2013. Organochlorine pesticide residue levels in river water and sediment from cocoa-producing areas of Ondo state central senatorial district, Nigeria. Journal of Environmental Chemistry and Ecotoxicology 5 (9), 242-249.

Jankowska, K., Ciesielczyk, F., Bachosz, K., Zdarta, J., Kaczorek, E., Jesionowski, T., 2019. Laccase immobilized onto zirconia-silica hybrid doped with $\mathrm{Cu} 2+$ as an effective biocatalytic system for decolorization of dyes. Materials 12 (8), 1252.

Jayaraj, R., Megha, P., Sreedev, P., 2016. Organochlorine pesticides, their toxic effects on living organisms and their fate in the environment. Interdiscip. Toxicol. 9 (3-4), $90-100$

Jin, X., Yu, X., Zhu, G., Zheng, Z., Feng, F., Zhang, Z., 2016. Conditions optimizing and application of laccase-mediator system (LMS) for the laccase-catalyzed pesticide degradation. Sci. Rep. 6, 35787.

Jokanović, M., 2018. Neurotoxic effects of organophosphorus pesticides and possible association with neurodegenerative diseases in man: a review. Toxicology 410 , $125-131$.

Kafilzadeh, F., 2015. Distribution and sources of polycyclic aromatic hydrocarbons in water and sediments of the Soltan Abad River, Iran. Egypt. J. Aquat. Res. 41, $227-231$.

Karigar, C.S., Rao, S.S., 2011. Role of microbial enzymes in the bioremediation of pollutants: a review. Enzyme research 2011, 805187, (11 pages).

Katayama, A., Matsumura, F., 1993. Degradation of organochlorine pesticides, particularly endosulfan, by Trichoderma harzianum. Environmental Toxicology and Chemistry: An International Journal 12 (6), 1059-1065.

Kim, K.H., Kabir, E., Jahan, S.A., 2017. Exposure to pesticides and the associated human health effects. Sci. Total Environ. 575, 525-535.

Köck-Schulmeyer, M., Postigo, C., Farré, M., Barceló, D., de Alda, M.L., 2019. Medium to highly polar pesticides in seawater: analysis and fate in coastal areas of Catalonia (NE Spain). Chemosphere 215, 515-523.

Kumar, B., Mishra, M., Verma, V.K., Rai, P., Kumar, S., 2018. Organochlorines in urban soils from Central India: probabilistic health hazard and risk implications to human population. Environ. Geochem. Health 40 (6), 2465-2480.

Kupski, L., Salcedo, G.M., Caldas, S.S., de Souza, T.D., Furlong, E.B., Primel, E.G., 2019. Optimization of a laccase-mediator system with natural redox-mediating compounds for pesticide removal. Environ. Sci. Pollut. Res. 26 (5), 5131-5139.

Lafi, W.K., Al-Qodah, Z., 2006. Combined advanced oxidation and biological treatment processes for the removal of pesticides from aqueous solutions. J. Hazard. Mater. 137 (1), 489-497.

Le Person, A., Mellouki, A., Munoz, A., Borras, E., Martin-Reviejo, M., Wirtz, K., 2007. Trifluralin: photolysis under sunlight conditions and reaction with HO radicals. Chemosphere 67 (2), 376-383.

Y.H.H.H.J.I.J.H., J.Y.. Sci. Total Environ.

$\mathrm{Li}, \mathrm{Z}$., 2018. Health risk characterization of maximum legal exposures for persistent organic pollutant (POP) pesticides in residential soil: an analysis. J. Environ. Manag. 205, 163-173.

Liao, X., Zhang, C., Wang, Y., Tang, M., 2017. The abiotic degradation of methyl parathion in anoxic sulfur-containing system mediated by natural organic matter. Chemosphere 176, 288-295.

Lin, Q.S., Chen, S.H., Hu, M.Y., Haq, M.U., Yang, L., Li, H., 2011. Biodegradation of cypermethrin by a newly isolated actinomycetes HU-S-01 from wastewater sludge. International Journal of Environmental Science \& Technology 8 (1), 45-56.

Liu, L., Bilal, M., Duan, X., Iqbal, H.M., 2019. Mitigation of environmental pollution by genetically engineered bacteria-current challenges and future perspectives. Sci. Total Environ. 667, 444-454. 
Luo, D., Zhou, T., Tao, Y., Feng, Y., Shen, X., Mei, S., 2016. Exposure to organochlorine pesticides and non-Hodgkin lymphoma: a meta-analysis of observational studies. Sci. Rep. 6, 25768.

Maqbool, Z., Hussain, S., Imran, M., Mahmood, F., Shahzad, T., Ahmed, Z., ... Muzammil, S., 2016. Perspectives of using fungi as bioresource for bioremediation of pesticides in the environment: a critical review. Environ. Sci. Pollut. Res. 23 (17), $16904-16925$.

Mehrpour, O., Karrari, P., Zamani, N., Tsatsakis, A.M., Abdollahi, M., 2014. Occupational exposure to pesticides and consequences on male semen and fertility: a review. Toxicol. Lett. 230 (2), 146-156.

Mir-Tutusaus, J.A., Baccar, R., Caminal, G., Sarrà, M., 2018. Can white-rot fungi be a real wastewater treatment alternative for organic micropollutants removal? A review. Water Res. 138, 137-151.

Moon, Y., Jafry, A.T., Kang, S.B., Seo, J.Y., Baek, K.Y., Kim, E.J., ... Jeong, K., 2019 . Organophosphorus hydrolase-poly- $\beta$-cyclodextrin as a stable self-decontaminating bio-catalytic material for sorption and degradation of organophosphate pesticide. J. Hazard. Mater. 365, 261-269.

Morillo, E., Villaverde, J., 2017. Advanced technologies for the remediation of pesticide-contaminated soils. Sci. Total Environ. 586, 576-597.

Nandipati, S., Litvan, I., 2016. Environmental exposures and Parkinson's disease. Int. J. Environ. Res. Public Health 13 (9), 881.

Nigam, V.K., Shukla, P., 2015. Enzyme based biosensors for detection of environmental pollutants-a review. J. Microbiol. Biotechnol. 25 (11), 1773-1781.

Nkya, T.E., Akhouayri, I., Kisinza, W., David, J.P., 2013. Impact of environment on mosquito response to pyrethroid insecticides: facts, evidences and prospects. Insect Biochem. Mol. Biol. 43 (4), 407-416.

Ortiz-Hernández, M.L., Sánchez-Salinas, E., Dantán-González, E., Castrejón-Godínez, M.L., 2013. Pesticide biodegradation: mechanisms, genetics and strategies to enhance the process. In: Biodegradation-life of Science. pp. 251-287.

Pereira, L.C., de Souza, A.O., Bernardes, M.F.F., Pazin, M., Tasso, M.J., Pereira, P.H., Dorta, D.J., 2015. A perspective on the potential risks of emerging contaminants to human and environmental health. Environ. Sci. Pollut. Res. 22 (18), 13800-13823.

Pico, Y., El-Sheikh, M.A., Alfarhan, A.H., Barceló, D., 2018. Target vs non-target analysis to determine pesticide residues in fruits from Saudi Arabia and influence in potential risk associated with exposure. Food Chem. Toxicol. 111, 53-63.

Pizzul, L., Castillo, M.D., Stenström, J., 2009. Degradation of glyphosate and other pesticides by ligninolytic enzymes. Biodegradation 20 (6), 751.

Porzio, E., Merone, L., Mandrich, L., Rossi, M., Manco, G., 2007. A new phosphotriesterase from Sulfolobus acidocaldarius and its comparison with the homologue from Sulfolobus solfataricus. Biochimie 89 (5), 625-636.

Rani, M., Shanker, U., Jassal, V., 2017. Recent strategies for removal and degradation of persistent \& toxic organochlorine pesticides using nanoparticles: a review. J. Environ. Manag. 190, 208-222.

Rodríguez-Delgado, M., Orona-Navar, C., García-Morales, R., Hernandez-Luna, C., Parra, R., Mahlknecht, J., Ornelas-Soto, N., 2016. Biotransformation kinetics of pharmaceutical and industrial micropollutants in groundwaters by a laccase cocktail from Pycnoporus sanguineus CS43 fungi. Int. Biodeterior. Biodegradation 108 , 34- 41 .

Sabarwal, A., Kumar, K., Singh, R.P., 2018. Hazardous effects of chemical pesticides on human health-cancer and other associated disorders. Environ. Toxicol. Pharmacol. 63, 103-114.

Schenk, G., Mateen, I., Ng, T.K., Pedroso, M.M., Mitić, N., Jafelicci Jr, M., ... Ollis, D.L., 2016. Organophosphate-degrading metallohydrolases: structure and function of potent catalysts for applications in bioremediation. Coord. Chem. Rev. 317, $122-131$.

Sharma, A., Gangola, S., Khati, P., Kumar, G., Srivastava, A., 2016. Novel pathway of cypermethrin biodegradation in a Bacillus sp. strain SG2 isolated from cypermethrin-contaminated agriculture field. 3 Biotech $6(1), 45$.

Shi, H., Peng, J., Li, J., Mao, L., Wang, Z., Gao, S., 2016. Laccase-catalyzed removal of the antimicrobials chlorophene and dichlorophen from water: reaction kinetics, pathway and toxicity evaluation. J. Hazard. Mater. 317, 81-89.

Simonelli, A., Basilicata, P., Miraglia, N., Castiglia, L., Guadagni, R., Acampora, A., Sannolo, N., 2007. Analytical method validation for the evaluation of cutaneous occupational exposure to different chemical classes of pesticides. J. Chromatogr. B 860 (1), 26-33.

Singh, B.K., Walker, A., Morgan, J.A.W., Wright, D.J., 2004. Biodegradation of chlorpyrifos by Enterobacter strain B-14 and its use in bioremediation of contaminated soils. Appl. Environ. Microbiol. 70 (8), 4855-4863.

Singh, N.S., Sharma, R., Parween, T., Patanjali, P.K., 2018. Pesticide contamination and human health risk factor. In: Modern Age Environmental Problems and their Remediation. Springer, Cham, pp. 49-68
Sørensen, S.R., Bending, G.D., Jacobsen, C.S., Walker, A., Aamand, J., 2003. Microbial degradation of isoproturon and related phenylurea herbicides in and below agricultural fields. FEMS Microbiol. Ecol. 45 (1), 1-11.

Sylvie Azandjeme, C., Bouchard, M., Fayomi, B., Djrolo, F., Houinato, D., Delisle, H., 2013. Growing burden of diabetes in sub-saharan Africa: contribution of pesticides?. Curr. Diabetes Rev. 9 (6), 437-449.

Tatarková, V., Hiller, E., Vaculík, M., 2013. Impact of wheat straw biochar addition to soil on the sorption, leaching, dissipation of the herbicide (4-chloro-2-methylphenoxy) acetic acid and the growth of sunflower (Helianthus annuus L.). Ecotoxicol. Environ. Saf. 92, 215-221.

Trovaslet-Leroy, M., Jolivalt, C., Froment, M.T., Brasme, B., Lefebvre, B., Daveloose, D., ... Masson, P., 2010. Application of laccase-mediator system (LMS) for the degradation of organophosphorus compounds. Chem. Biol. Interact. 187 (1-3), 393-396.

Varjani, S.J., Joshi, R.R., Kumar, P.S., Srivastava, V.K., Kumar, V., Banerjee, C., Kumar, R.P., 2018. Polycyclic aromatic hydrocarbons from petroleum oil industry activities: effect on human health and their biodegradation. In: Varjani, S.J., Gnansounou, E., Gurunathan, B., Pant, D., Zakaria, Z.A. (Eds.), Waste Bioremediation. Springer Nature, Singapore, pp. 185-199.

Vera, M., Nyanhongo, G.S., Pellis, A., Rivas, B.L., Guebitz, G.M., 2019. Immobilization of Myceliophthora thermophila laccase on poly (glycidyl methacrylate) microspheres enhances the degradation of azinphos-methyl. J. Appl. Polym. Sci. 136 (16), 47417.

Vidal-Limon, A., García Suárez, P.C., Arellano-García, E., Contreras, O.E., Aguila, S.A., 2018. Enhanced degradation of pesticide dichlorophen by laccase immobilized on nanoporous materials: a cytotoxic and molecular simulation investigation. Bioconjug. Chem. 29 (4), 1073-1080.

Vitola, G., Mazzei, R., Poerio, T., Porzio, E., Manco, G., Perrotta, I., ... Giorno, L., 2019. Biocatalytic membrane reactor development for organophosphates degradation. J. Hazard. Mater. 365, 789-795.

Wandiga, S.O., 2001. Use and distribution of organochlorine pesticides. The future in Africa. Pure Appl. Chem. 73 (7), 1147-1155.

Wang, F., Hu, Y., Guo, C., Huang, W., Liu, C.Z., 2012. Enhanced phenol degradation in coking wastewater by immobilized laccase on magnetic mesoporous silica nanoparticles in a magnetically stabilized fluidized bed. Bioresour. Technol. 110 $120-124$.

Wang, A., Cockburn, M., Ly, T.T., Bronstein, J.M., Ritz, B., 2014. The association between ambient exposure to organophosphates and Parkinson's disease risk. Occup. Environ. Med. 71 (4), 275-281.

Wang, S., Gao, B., Li, Y., Creamer, A.E., He, F., 2017. Adsorptive removal of arsenate from aqueous solutions by biochar supported zero-valent iron nanocomposite: batch and continuous flow tests. J. Hazard. Mater. 322, 172-181.

Yahaya, A., Okoh, O., Okoh, A., Adeniji, A., 2017. Occurrences of organochlorine pesticides along the course of the Buffalo River in the eastern cape of South Africa and its health implications. Int. J. Environ. Res. Public Health 14 (11), 1372.

Yan, D., Zhang, Y., Liu, L., Yan, H., 2016. Pesticide exposure and risk of Alzheimer's disease: a systematic review and meta-analysis. Sci. Rep. 6, 32222.

Yang, Y.X., Pi, N., Zhang, J.B., Huang, Y., Yao, P.P., Xi, Y.J., Yuan, H.M., 2016. US$\mathrm{PIO}$ assisting degradation of MXC by host/guest-type immobilized laccase in AOT reverse micelle system. Environ. Sci. Pollut. Res. 23 (13), 13342-13354.

Yang, Y., Xu, Y., Yang, Y., Yang, H., Yuan, H., Huang, Y., Liu, X., 2016. Laccase immobilized on mesoporous $\mathrm{SiO}_{2}$ and its use for degradation of chlorophenol pesticides. Russ. J. Phys. Chem. A 90 (10), 2044-2054.

Zdarta, J., Antecka, K., Frankowski, R., Zgoła-Grześkowiak, A., Ehrlich, H., Jesionowski, T., 2018. The effect of operational parameters on the biodegradation of bisphenols by Trametes versicolor laccase immobilized on Hippospongia communis spongin scaffolds. Sci. Total Environ. 615, 784-795.

Zdarta, J., Meyer, A.S., Jesionowski, T., Pinelo, M., 2018. Developments in support materials for immobilization of oxidoreductases: a comprehensive review. Adv. Colloid Interf. Sci. 258, 1-20.

Zeng, S., Qin, X., Xia, L., 2017. Degradation of the herbicide isoproturon by laccase-mediator systems. Biochem. Eng. J. 119, 92-100.

Zhang, P., Sun, H., Yu, L., Sun, T., 2013. Adsorption and catalytic hydrolysis of carbaryl and atrazine on pig manure-derived biochars: impact of structural properties of biochars. J. Hazard. Mater. 244, 217-224.

Zhao, Y.C., Yi, X.Y., Zhang, M., Liu, L., Ma, W.J., 2010. Fundamental study of degradation of dichlorodiphenyltrichloroethane in soil by laccase from white rot fungi. International Journal of Environmental Science \& Technology 7 (2), $359-366$. 